\title{
Mississippian-like rugose corals from a Bashkirian biostrome in the Tindouf Basin, S. Morocco
}

\author{
Sergio RODRÍGUEZ ${ }^{1,2 *}$, Ian D. SOMERVILLE ${ }^{3}$, Ismail SAID ${ }^{1,4}$ \& Pedro CÓZAR ${ }^{2}$
}

\footnotetext{
${ }^{1}$ Departamento de Paleontología, Facultad de Ciencias Geológicas, UCM, c/José Antonio Novais, 2. 28040 Madrid, Spain; sergrodr@geo.ucm.es ${ }^{2}$ Departamento de Geología Sedimentaria y Cambio Medioambiental, Instituto de Geociencias, CSIC, UCM, c/José Antonio Novais, 2, 28040 Madrid, Spain; pcozar@geo.ucm.es

${ }^{3}$ UCD School of Geological Sciences, University College Dublin, Belfield, Dublin 4, Ireland; Ian.Somerville@ucd.ie

${ }^{4}$ Division du Patrimoine Géologique (DPG), Direction du Développement Minier (DDM), Ministère de l'Énergie, des Mines, de l'Eau et de l'Environnement, Rue Abou Marouane Essadi BP: Rabat Instituts 6208 - Haut Agdal, Rabat, Morocco

* Corresponding author
}

Rodríguez, S., Somerville, I.D., Said, I. \& Cózar, P. 2013. Mississippian-like rugose corals from a Bashkirian biostrome in the Tindouf Basin, S. Morocco. [Corales rugosos de tipo Misisípico de un biostromo en la Cuenca de Tindouf, S. Marruecos]. Spanish Journal of Palaeontology, 28 (2), 253-282.

\begin{abstract}
A rich rugose coral assemblage has been recorded from a biostrome at the top of the Djebel Ouarkziz Fm. in the Tindouf Basin, S. Morocco. It is composed of 10 genera and 14 species, of which 5 are new: Dibunophyllum bipartitum, Arachnolasma sp., Palaeosmilia murchisoni, Palaeosmilia ressoti, Palastraea regia, Siphonodendron tindoufense sp. nov., Siphonodendron ouarkzizense sp. nov., Diphyphyllum maximum, Axophyllum moroccoense sp. nov., Gangamophyllum sp., Axoclisia sahariense sp. nov., Axoclisia cf. coronata, Actinocyathus sarytschevae and Actinocyathus mariae sp. nov. It represents essentially a Mississippian-type coral fauna but with some evolved species. However, its age, as determined by foraminifers, is early Bashkirian (Early Pennsylvanian). The presence of Mississippian-like corals in the Bashkirian indicates that the epicontinental basins in northern Gondwana (Saharan basins) were a refuge for coral faunas during the late Serpukhovian extinction event. The persistence of the Mississippian assemblages in the Bashkirian from northern Gondwana was probably due to a combination of warm waters and tectonic stability. The coral assemblage from the Tindouf biostrome is similar to those
\end{abstract}

\section{RESUMEN}

Una diversa asociación de corales rugosos ha sido recolectada de un biostromo a techo de la Formación Djebel Ouarkziz en la Cuenca de Tindouf. Se compone de 10 géneros y 14 especies, de las cuales 5 son nuevas: Dibunophyllum bipartitum, Arachnolasma sp., Palaeosmilia murchisoni, Palaeosmilia ressoti, Palastraea regia, Siphonodendron tindoufense sp. nov., Siphonodendron ouarkzizense sp. nov., Diphyphyllum maximum, Axophyllum moroccoense sp. nov., Gangamophyllum sp., Axoclisia sahariense sp. nov., Axoclisia cf. coronata, Actinocyathus sarytschevae y Actinocyathus mariae sp. nov. Representa fundamentalmente una asociación de corales tipo Misisípico con algunas especies evolucionadas. Sin embargo, su edad, determinada por foraminíferos, es Bashkiriense inferior (Pensilvánico inferior). La presencia de corales de tipo Misisípico en el Bashkiriiense indica que las cuencas epicontinentales del norte de Gondwana (cuencas saharianas) fueron un refugio para las faunas de corales durante el evento de extinción del Serpukhoviense. La persistencia de las asociaciones Misisípicas en el Bashkiriense del norte de Gondwana fue probablemente debida a una combinación de aguas cálidas y estabilidad tectónica. La asociación de 
corals recorded from Ellesmere Island, Arctic Canada and Novaya Zemlya, Arctic Russia where similar tropical warm water conditions have been identified during the Bashkirian in the northern hemisphere.

Keywords: Rugosa, biostrome, Djebel Ouarkziz, Tindouf Basin, Carboniferous, Morocco. corales del biostromo de Tindouf es similar a las registradas en la Isla de Ellesmere en el ártico canadiense y en Nueva Zembla, en el ártico ruso, donde condiciones semejantes de aguas cálidas y estabilidad tectónica se registraron durante el Bashkiriense, en este caso en el hemisferio norte.

Palabras clave: Rugosa, Djebel Ouarkziz, Cuenca de Tindouf, Carbonífero, Marruecos.

\section{INTRODUCTION}

The Tindouf Basin is a large syncline $(500 \mathrm{~km}$ in length and $300 \mathrm{~km}$ wide) located mainly in western Algeria, but covering also extensive areas in southern Morocco and Mauritania (Fig. 1). It comprises Palaeozoic rocks from Mountain Ordovician to Carboniferous age. The Djebel Ouarkziz range is located in the northern limb of the syncline, and is composed mostly of Mississippian rocks. It extends for about $300 \mathrm{~km}$ in a WSW-ENE direction between southern Morocco and western Algeria (Fig. 1). Five formations have been described there: Djebel Tazout Fm. (Strunian-Tournaisian), Betaina Fm. (TournaisianViséan), Djebel Ouarkziz Fm. (Viséan-Serpukhovianbasal Bashkirian), Djebel Reouina Fm (Namurian) and the Merkala Fm. (Westphalian-Stephanian) (Fig. 2). Rugose corals are only common in the Djebel Ouarkziz Formation, although rare undissepimented rugose corals have been recorded in the Betaina Formation. The Djebel Ouarkziz Formation shows mainly marine shales, sandstones and limestones and is informally divided into lower, middle and upper members (Conrad, 1985; Fig. 2).

The rugose corals of the Djebel Ouarkziz Formation have been mentioned and/or described by Menchikoff \& Hsu (1935), Fabre (1955), Mamet et al. (1966), SemenoffTian-Chansky (1974, 1985), Aretz (2011), Rodríguez et al. (2011, 2013) and Somerville et al. (2013). Most studies have been focused on the rich coral assemblages recorded in the many limestone beds of the lower member (Menchikoff \& Hsu, 1935; Semenoff-Tian-Chansky, 1985; Rodríguez et al., 2011, 2013). The upper member shows evaporites, shales and mudstones with very few or absent macrofauna. However, two beds at the top of the limestone succession have yielded a significant assemblage containing corals, brachiopods and chaetetids. The top of the Djebel Ouarkziz Formation is represented by the Titanaria bed (Conrad \& Legrand-Blain, 1971). The limestone bed located immediately below it shows a rich assemblage of rugose corals, with a dominance of fasciculate corals showing small corallites (Semenoff-Tian-Chansky, 1985). This coral-rich horizon was first named by Fabre (1955) as the "limestone with Lithostrotion junceum". Subsequently
Mamet et al. (1966) referred to it as the "biostrome of L. junceum" and more recently Semenoff-Tian-Chansky (1985) called it the "bed with Lithostrotion cf. junceum" and Legrand-Blain et al. (1989) termed it the "conspicuous Siphonodendron biostrome allied to S. pauciradiale".

However, only a partial description of the assemblage was achieved by Fabre (1955), who described two taxa: Caninophyllum archiaci (Milne-Ewards \& Haime, 1852) and the new species Carcinophyllum coronatum from Oum el Achar (Algeria). Semenoff-Tian-Chansky (1974) described from that bed (also in the Algerian part of the Djebel Ouarkziz mountain range) the following solitary rugose taxa: Dibunophyllum bipartitum (McCoy, 1849), Palaeosmilia murchisoni Milne-Edwards \& Haime, 1848, Palaeosmilia ressoti Menchikoff \& Hsu, 1935 and Axophyllum? coronatum Fabre, 1955. Later, the same author (Semenoff-Tian-Chansky, 1985) referred to the most abundant coral in this biostrome as Siphonodendron sp. A, but he did not describe or figure it. Semenoff-TianChansky (1985) also indicated the presence of a species of 'Lonsdaleia' close to ' $L$ '. sarytschevae Dobrolyubova, 1958 and Axophyllum? coronatum from the same horizon.

\section{THE BIOSTROME}

The biostrome was described first from Oum el Achar (Algeria), at the eastern end of the Djebel Ouarkziz range, but it has a large lateral extension reaching to the western border of the basin in Morocco and cropping out for more than $300 \mathrm{~km}$, together with most of the limestone beds. Mamet et al. (1966) identified the biostrome in the TinguizRemz section in the Moroccan part of the mountain range. Semenoff-Tian- Chansky (1985) and LegrandBlain et al. (1989) cited the presence of analogous beds with similar rugose coral assemblages in the Reggan and Ahnet basins in Algeria over $1000 \mathrm{~km}$ to the southeast, and in the Taoudenni Basin in Mali, $c a .800 \mathrm{~km}$ to the south (Fig. 1c).

However, the outcrop of the biostrome in the Djebel Ouarkziz is not continuously exposed. The upper member of the Djebel Ouarkziz Formation is mainly composed of 


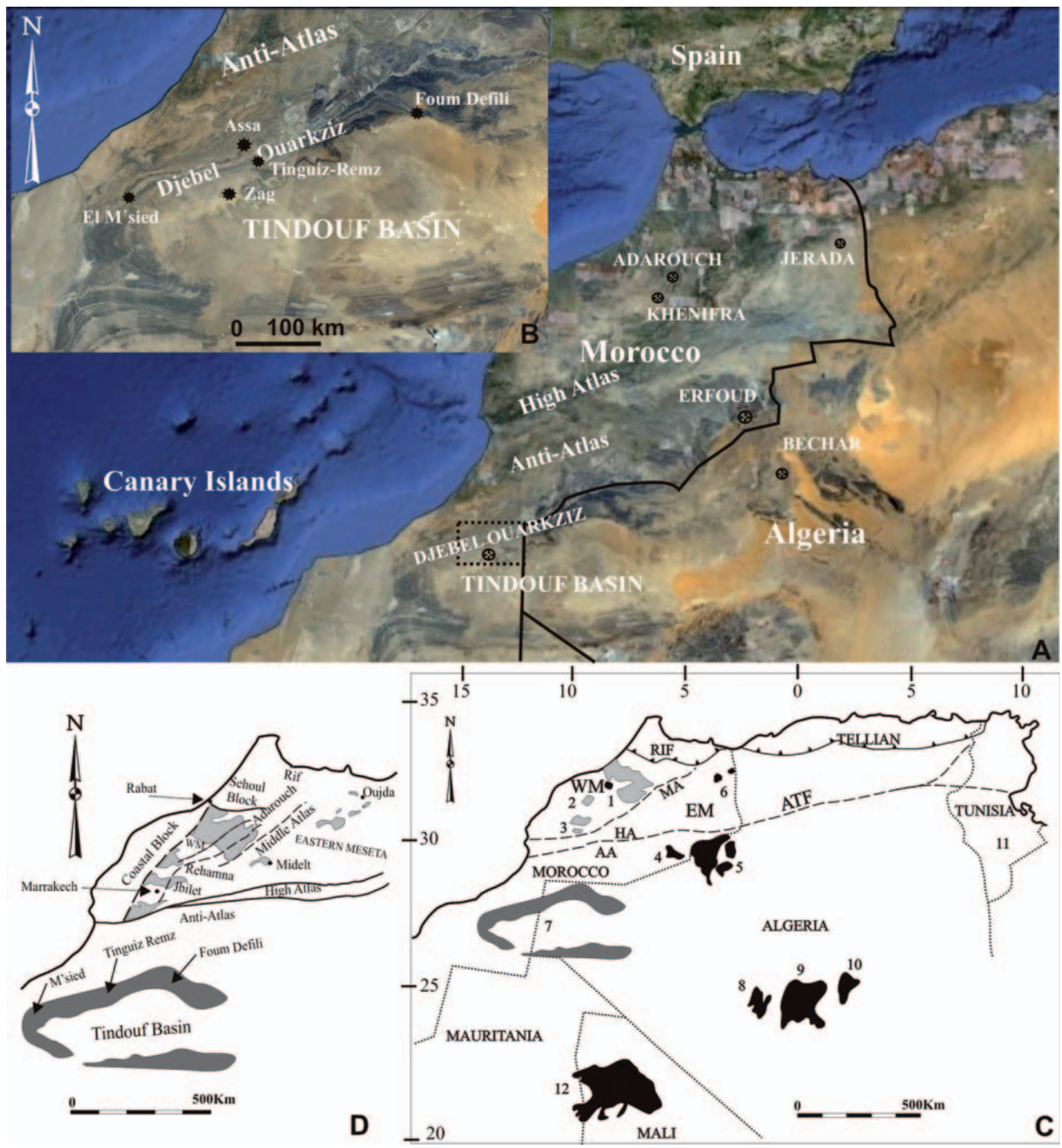

Figure 1. A-B) Aerial view of the northern flank of the Tindouf Syncline and Basin. C) Location of the main Carboniferous outcrops and basins in Morocco, Algeria, Mali and subsurface in Tunisia, 1 Central Meseta (Azrou-Khenifra), 2 Rehamna, 3 Jebilet, 4 Tafilalt, 5 Béchar, 6 Jerada, 7 Tindouf, 8 Reggan, 9 Ahnet, 10 Mouydir, 11 subsurface Carboniferous (number is situated in the map where the boreholes intersected Carboniferous rocks in Tunisia), 12 Taoudenni, AA Anti-Atlas, ATF Atlas Transform Fault, EM Eastern Meseta, HA High Atlas, MA Middle Atlas, WM Western Meseta. D) Detail of the Variscides and Tindouf Basin in Morocco, pale grey areas are Carboniferous outcrops, dark grey is the Tindouf Basin outcrop (modified from Rodríguez et al., 2013; Somerville et al., 2013).

shales, micrites and evaporites. Consequently, it forms a low terrain or plain in the southern border of the Djebel Ouarkziz escarpment, whose main topographic high is produced by the limestones of the lower member. In some areas (e.g., the main section at the road from Assa to Zag) it is covered by a hammada. It crops out near TinguizRemz, but, unfortunately, can no longer be examined there because of access problems (it lies within a restricted military area). The biostrome also occurs in a section 10 $\mathrm{km}$ west of the road from Assa to Zag and $1 \mathrm{~km}$ south of 


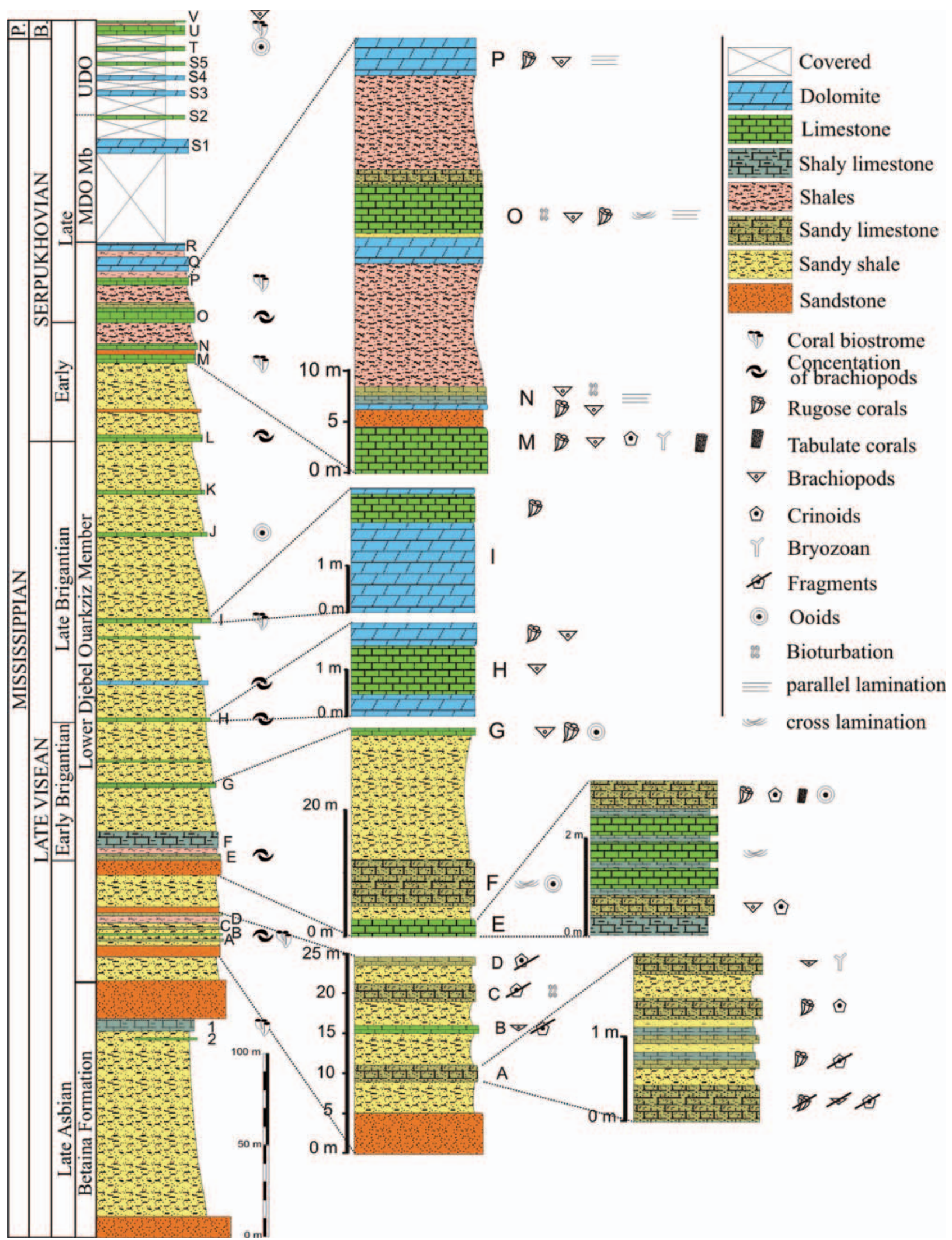

Figure 2. Synthetic log of the Djebel Ouarkziz Formation in the Assa region (after Rodríguez et al., 2013; Somerville et al., 2013). 
the last continuous ridge of the middle member (Fig. 3). It is accessible by a track, where it forms a low ridge amid the plain (Figs 4a-4b; coordinates, $28^{\circ} 21^{\prime} 20^{\prime \prime} \mathrm{N}, 9^{\circ} 29^{\prime} 04^{\prime \prime}$ $\mathrm{W})$. Here we could study the biostrome in detail. It attains a thickness of $4.5 \mathrm{~m}$ and is followed by $1 \mathrm{~m}$ of marls and the Titanaria bed, which is composed of 50-60 cm of sandy limestone with large brachiopods (Fig. 4b). The Titanaria bed is succeeded by unfossiliferous shales and sandstones of the siliciclastic-dominant Djebel Reouina Fm. of Early Pennsylvanian age. These continental deposits in Morocco have been related to the Chokierian regression (LegrandBlain et al., 1989).

As explained previously, the biostrome of the upper member of the Djebel Ouarkziz Formation is at the top of a sequence of shales, evaporites and lime mudstones that show an almost complete absence of macrofauna, just some rare gastropods, brachiopods and crinoidal plates. However, the top beds show a diverse assemblage in addition to the corals: brachiopods, crinoids, chaetetids and bryozoans are common there. The rugose corals are especially abundant at the top of the limestone bed, where they build an autobiostrome with many corals in growth position (Figs 4c-4e). However, many fragments of corals are dominant in the lower part of the bed. They may be regarded as storm layers.
A diverse set of microfacies have been observed in thin sections. The most abundant one is rudstone; bindstone and packstone are also common. More rarely, grainstone occur, mainly in the upper part of the bed. The identified components are the same as those occurring as macrofauna, plus foraminifers, calcareous algae, ostracods and scarce fragments of molluscs. Frequently, there is recorded the intergrowth of gigantoproductid brachiopods, rugose corals and chaetetid sponges.

Foraminiferal assemblages within the biostrome are rich and diverse. It can be highlighted the occurrence of Eostaffella postmosquensis, Eostaffellina ovaliformis, Globivalvulina kamensis, Globivalvulina minima, Iriclinella sp., Plectomillerella spp., Plectostaffella jakhensis, Plectostaffella spp. and Plectostaffella varvariensis that are taxa which first occur in the uppermost Serpukhovian (Zapatyulbian substage), although generally occur in the Bashkirian. In addition, Bradyina magna, Bradyina samarica, Eostaffellina monstruosa, Globivalvulina bulloides, Hemigordiellina spp., Hemigordius sp. and Semistaffella minuscularia are only known from Bashkirian rocks. The base of the Bashkirian (Voznessenian substage) is situated in slightly older beds, because in the biostrome, the foraminifers Semistaffella variabilis and the conodont Idiognathoides sulcatus sulcatus are also recorded. Those

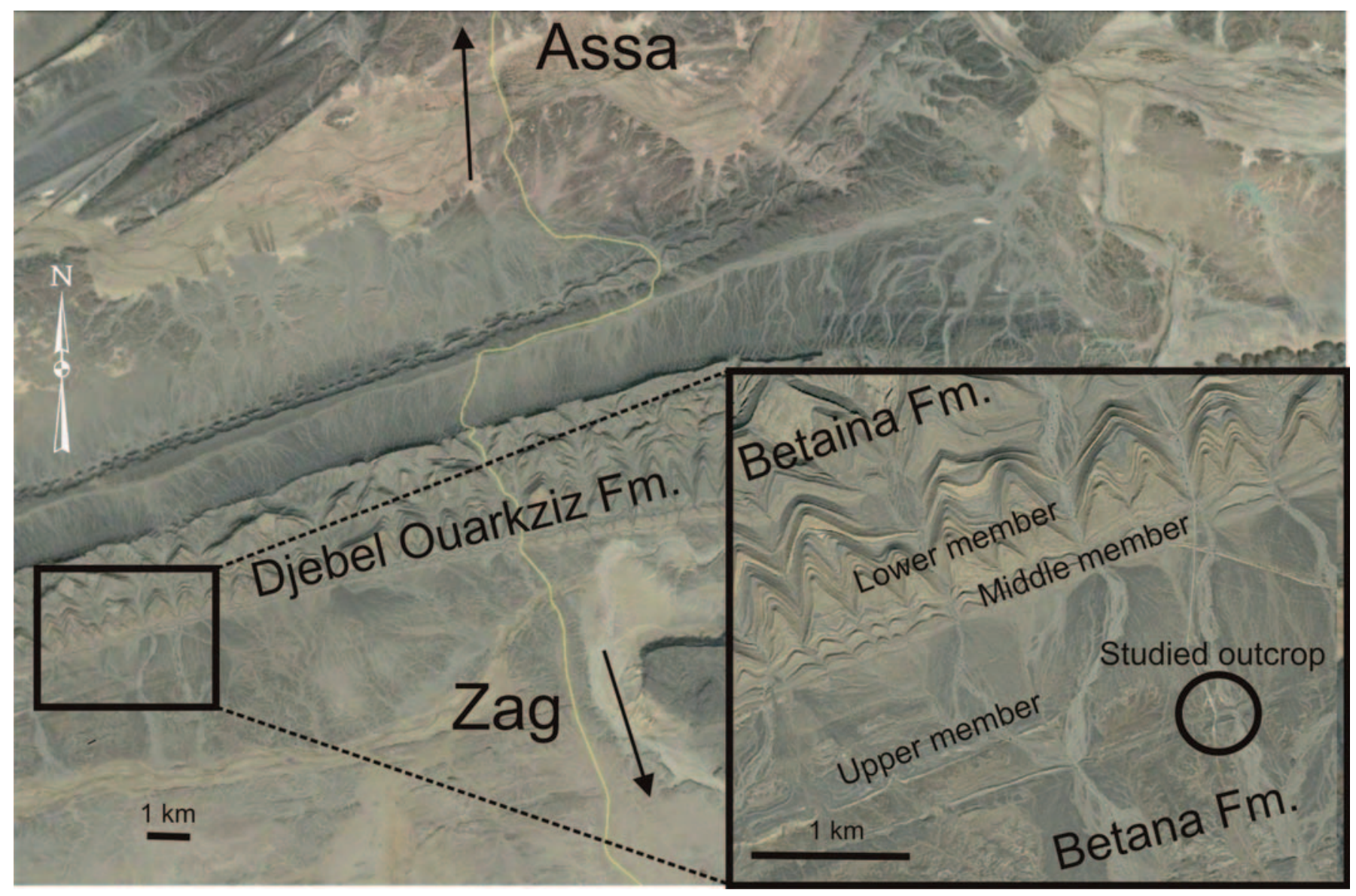

Figure 3. Location of the studied outcrop in the Djebel Ouarkziz. 

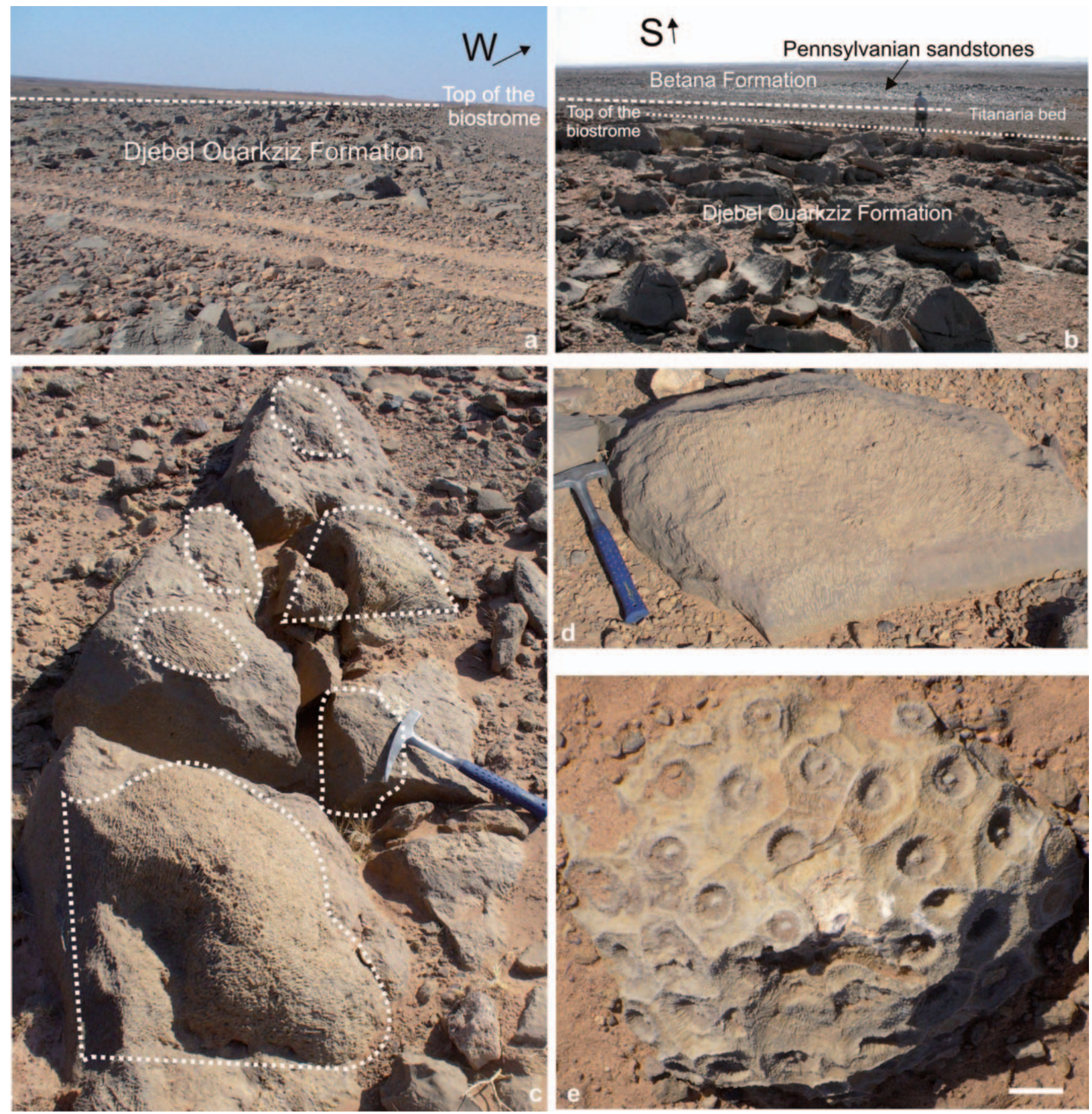

Figure 4. Outcrop of the biostrome and in situ colonies. a) View to the west showing the upper surface of the biostrome. b) View to the south, showing the upper surface of the biostrome, the Titanaria bed and the sandstones of the Djebel Reouina Formation. c) Siphonodendron colonies in growth position near the top of the biostrome. d) Large Siphonodendron colony. e) Colony of Actinocyathus mariae observed at outcrop. Scale bar $=10 \mathrm{~mm}$. Hammer in c) and d) $37 \mathrm{~cm}$ long.

taxa are zonal markers for foraminifers and conodonts of the Krasnopolyanian substage (= Kinderscoutian, lower part of the Namurian B, ammonoid Zone R1). Details of the assemblages are documented in Cózar et al. (in press).

\section{THE RUGOSE CORAL ASSEMBLAGE}

The rugose corals are abundant but not highly diverse in the biostrome. The assemblage is dominated by fasciculate colonies ( 3 species). Less abundant, but also well represented are massive colonies ( 3 species). Solitary corals are also abundant and more diverse ( 8 species). On 
the other hand, tabulate corals are completely absent in the biostrome.

The most abundant species is Siphonodendron tindoufense sp. nov., which is probably the coral that Fabre (1955) called Lithostrotion junceum and Semenoff-TianChansky (1985) referred to as Siphonodendron sp. A. The colonies show a large size range, from several centimetres to $1.5 \mathrm{~m}$ in diameter and up to $50 \mathrm{~cm}$ high. Corallites are small, between 3 to $5 \mathrm{~mm}$ in diameter and 15 to 20 major septa. A closely related species is Siphonodendron ouarkzizense sp. nov. that has corallites reaching 5 to $7 \mathrm{~mm}$ in diameter and 25 to 28 major septa. These species show similar dimensions to the Viséan species $S$. pauciradiale (McCoy, 1844) and S. irregulare (Phillips, 1836) respectively, but both species in the biostrome show a discontinuous columella and mainly flat tabulae.

The third fasciculate coral, Diphyphyllum maximum Poty, 1981 is much less abundant, but larger, with corallites 8 to $12 \mathrm{~mm}$ in diameter and 32 to 38 major septa.

The massive species are not abundant, but conspicuous in the outcrop. The most common species are Actinocyathus sarytschevae (Dobrolyubova, 1958) and Actinocyathus mariae sp. nov. (Fig. 4e). They form small cerioid colonies from 10 to 30 centimetres in diameter. The only difference between these two species is the number of septa; in the former, 33 to 35 , and in the latter 25 to 28 . The third massive species with astreoid-aphroid habit is Palastraea regia (Phillips, 1836), which has been recorded only as fragments of colonies.

Solitary corals are also abundant, but not diverse. We have identified 8 species belonging to 6 different genera and to 3 families: Axophyllidae (Gangamophyllum sp., Axophyllum moroccoense sp. nov., Axoclisia sahariense sp. nov. and Axoclisia cf. coronata), Aulophyllidae (Dibunophyllum bipartitum (McCoy) and Arachnolasma sp.) and Palaeosmiliidae (Palaeosmilia murchisoni MilneEdwards \& Haime and Palaeosmilia ressoti Menchikoff \& Hsu). More than $90 \%$ of all the recorded solitary specimens belong to either Dibunophyllum bipartitum or Axophyllum sahariense sp. nov.

This assemblage is quite similar to that described by Semenoff-Tian-Chansky $(1974,1985)$ in the Algerian eastern end of the Djebel Ouarkziz. However, neither of the corals Caninophyllum archiaci and Axophyllum? coronatum described by Fabre (1955) have been recorded in the Moroccan outcrops that we studied, but a specimen close to the latter species was collected.

\section{SYSTEMATIC PALAEONTOLOGY}

The terminology used for the descriptions is that proposed by Hill (1981) with some observations of Poty (1981). The microstructural descriptions are based on those of Semenoff-Tian-Chansky (1974) and Rodríguez (1984), but they are not extensive because they are based on observations made on thin sections and not on SEM or ultrathin sections. All the coral specimens collected from the biostrome in the upper member of the Djebel Ouarkziz Fm. in Tindouf Basin, including the type material, is reposited in Departamento de Paleontología, Universidad Complutense de Madrid (UCM) and catalogued as DO1/ $\mathrm{U}-1$ to $\mathrm{DO} 1 / \mathrm{U}-153$.

No synonymies are included, except for the new taxa. Complete synonymies for most rugose taxa can be found in the general monographs that deal with the same or similar taxa (Fedorowski, 1971; Semenoff-Tian-Chansky, 1974; Poty, 1981; Rodríguez et al., 2002; Said, 2005; Said \& Rodríguez, 2008).

\section{Phylum COELENTERATA Frey \& Leuckart, 1847 \\ Subphylum CNIDARIA Hatschek, 1888 \\ Class ANTHOZOA Ehrenberg, 1834 \\ Subclass RUGOSA Milne-Edwards \& Haime, 1850 \\ Family Aulophyllidae Dybowski, 1873 \\ Genus Dibunophyllum Thomson \& Nicholson, 1876}

Diagnosis (after Hill, 1940). Large, simple rugose coral, whose variable axial structure is typically one-third as wide as the corallum, and consists of a long median plate, a few (usually four to eight) septal lamellae on either side, and numerous tabellae, sloping steeply down at its periphery; less typically the lamellae may become curved, the median plate disappears, and the bilaterally radiate arrangement lost. Minor septa are degenerate; the width of the dissepimentarium is about two-thirds the length of the major septa, which is two-thirds the radius of the corallite; the dissepiments are frequently inosculating. Tabulae are incomplete and bracket-shaped; the tabellae are of two series, the plates of the outer series being fewer and less steeply declined than those of the inner series. The septa are not curved about the small fossula.

\section{Dibunophyllum bipartitum (McCoy, 1849)} (Figs 5, 6)

Material. 67 specimens (DO1/U-41, 43, 48, 60, 63, 68$71,73,74,78,79,82,84,87,90-120,126-140,142-146$, 149); 60 transverse and 20 longitudinal thin sections.

Location, Horizon and age. From the plain to the south of the Djebel Ouarkziz escarpment, $10 \mathrm{~km}$ west of the road from Zag to Assa, Tindouf Basin, S. Morocco. Biostrome (bed U), upper member, Djebel Ouarkziz Fm. early Bashkirian.

Diagnosis. Solitary, large coral with a variable axial structure that reach $1 / 3$ of the diameter. It is composed of a median lamella, a small number of radial lamellae and tabulae inclined to the periphery. The lamellae are usually anastomosed or winding. The dissepimentarium is 


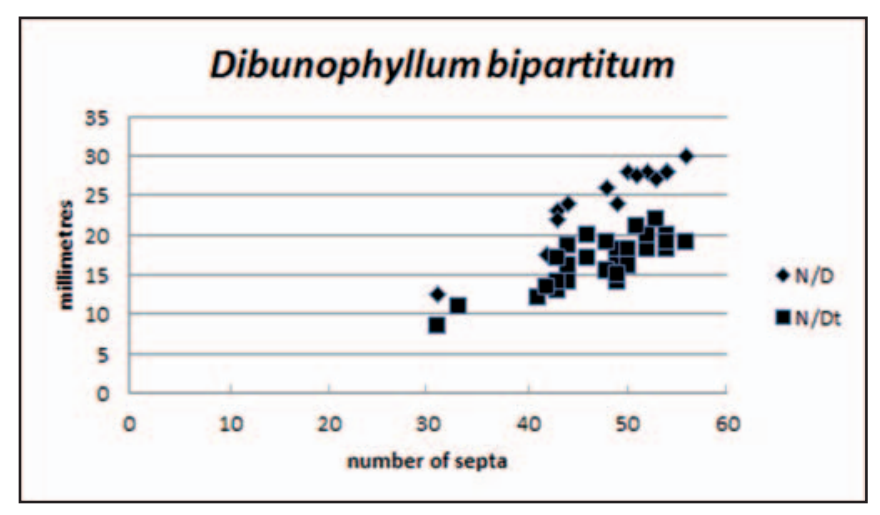

Figure 5. Plot of corallite diameter (D) and tabularium diameter (Dt) versus number of septa $(\mathrm{N})$ in Dibunophyllum bipartitum $(\mathrm{n}=67)$.

wide, with short minor septa and angulate to inosculate, occasionally regular dissepiments. In rare cases the minor septa are long, reaching the inner border of the dissepimentarium. The septa are commonly thick in the tabularium, mainly in the cardinal quadrants. The tabulae are incomplete, tent-shaped and divided in two series: axial and periaxial. The wall is lamellar with fibrous intercalations. The septa show a thin, irregular mesoplasm. The stereoplasm only occurs in the outer parts of the septa, and on some dissepiments or tabulae (after Semenoff-TianChansky, 1974).

Description. Large solitary corals, trochoid to ceratoid. The alar diameter in adult stages varies from 20 to 30 $\mathrm{mm}$. The tabularium diameter varies from 12 to $22 \mathrm{~mm}$. The wall is thin and smooth, but it is eroded in most specimens.

It shows 40 to 56 major septa in adult stages (Fig. 5). They are thin and irregular in the dissepimentarium, somewhat thickened and straight in the tabularium. The cardinal septum is shorter than other major septa and is located in a small, not very conspicuous fossula. Minor septa are short and irregular or absent, very rarely reaching the dissepimentarium/tabularium boundary.

The dissepimentarium occupies about $1 / 3$ of the radius. It is composed of up to 12 rows of angulate to inosculate dissepiments. The inner row of dissepiments (and in some cases two or three additional rows) is composed of regular dissepiments and often thickened. In longitudinal section they are long and very steeply declined (Figs 6b, 6f, 6i).

The axial structure is large and complex. Its diameter varies from 7 to $10 \mathrm{~mm}$ (compare Figs $6 \mathrm{c}, 6 \mathrm{~g}, 6 \mathrm{j}$ ). The median lamella is long and it is connected to the counter septum in some instances. In some specimens it is irregular and not very conspicuous. There are from 9 to 16 radial lamellae. They are short, sinuous and thin. Some of them are thinner close to the axial structure and do not joint the septal lamellae. The tabulae are thin, large and in transverse section 4 to 10 are intersected. In longitudinal section the peripheral tabulae are declined to the periphery, incomplete and convex. The axial tabulae are also highly divided in many tabellae. The general shape is conical, with higher inclination in the periphery.

The microstructure of the wall is microlamellar. The tabulae and dissepiments are microgranular with fibrous thickenings (Fig. 6m). The septa show mesoplasm with fibers organized in fascicles and fibronormal stereoplasm (Fig. 61). A thin lamellar layer may occur in the inner part of the stereoplasm.

Remarks. $D$. bipartitum shows a high intraspecific variability. Hill (1938) revised this species and regarded it as synonymous with more than 20 species belonging to several genera described by Thomson (1874) and Thomson $\&$ Nicholson (1876). The specimens from the Tindouf biostrome display a quite low variability and, in spite of the large time gap and great geographical distances, they do not show important differences with the upper Viséan specimens from N and NW Europe (Fedorowski, 1971; Khoa, 1977; Poty, 1981; Aretz, 2002; Denayer et al., 2011).

\section{Genus Arachnolasma Grabau, 1922}

Diagnosis (after Semenoff-Tian-Chansky, 1974). Solitary coral with well-developed dissepimentarium. Axial structure having a small diameter (about $1 / 5$ of the alar diameter), composed of a thick median lamella and a low number of radial lamellae. The axial tabulae are more-orless well differentiated from the rest of the tabularium and strongly declined from the median lamella to the periphery. Septa with two phases of secretion, with the stereoplasm fibrous or lamellar in different species.

\section{Arachnolasma sp.}

(Figs 7, 8)

Material. 3 specimens, DO1/U-64, 67, and 86; 3 transverse and 3 longitudinal thin sections.

Location, Horizon and age. From the plain to the south of the Djebel Ouarkziz escarpment, $10 \mathrm{~km}$ west of the road from Zag to Assa, Tindouf Basin, S. Morocco. Biostrome (bed U), upper member, Djebel Ouarkziz Fm. early Bashkirian.

Description. Fragments of solitary corals, which do not preserve the apex and most part of the dissepimentarium. Only in the specimen DO1/U-64 could the alar diameter be measured: $20 \mathrm{~mm}$. Tabularium diameter between 12 and $15 \mathrm{~mm}$. The number of major septa varies between 35 and 43 (Fig. 7). They are undulose, slightly thickened in the tabularium. Minor septa short or absent. Cardinal 

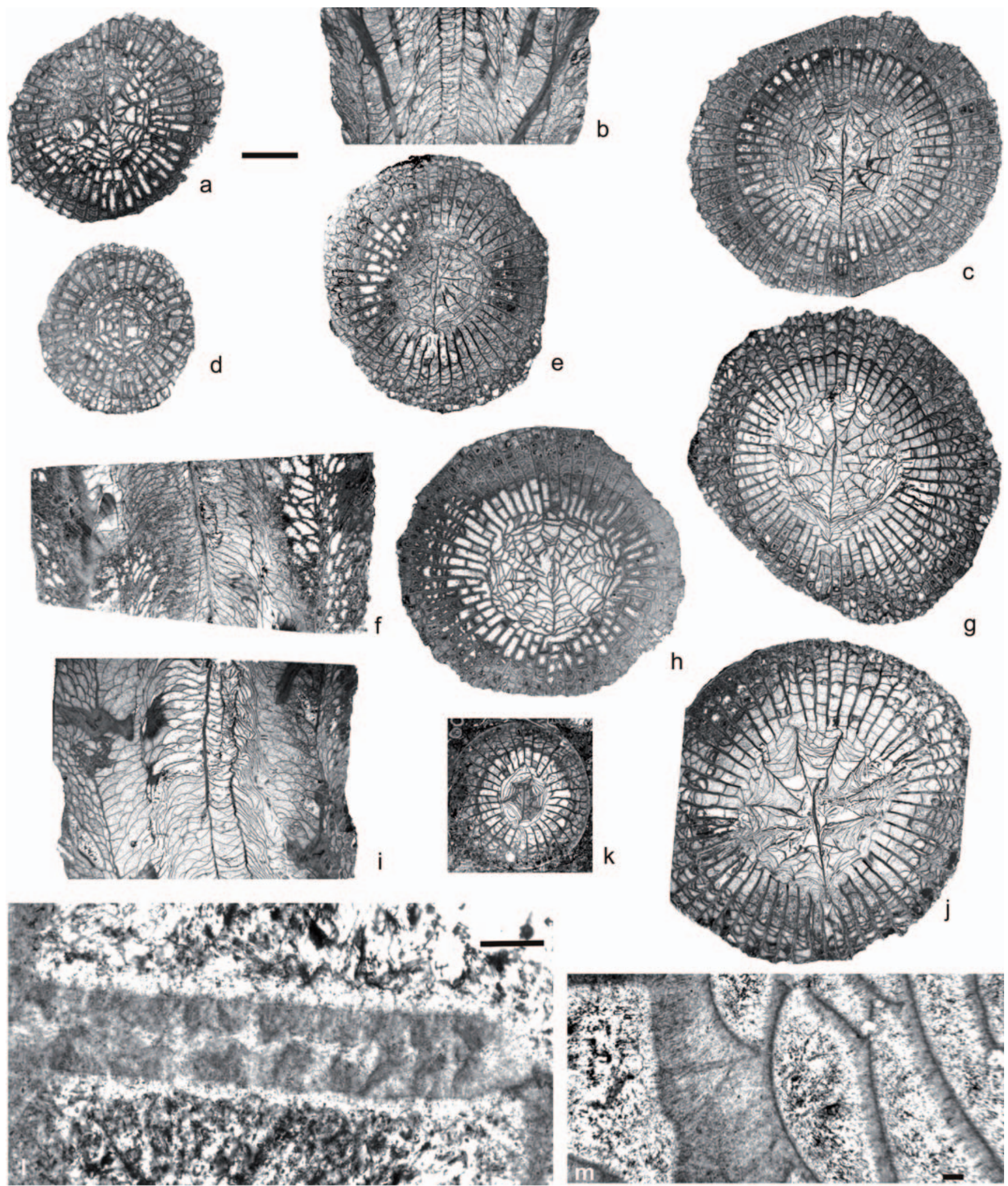

Figure 6. Dibunophyllum bipartitum. a-c) Specimen DO1/U-102; (a) transverse section in young stage; (b) longitudinal section; (c) transverse section in adult stage. d-e) Specimen DO1/U-103; (d) transverse section in young stage; (e) transverse section in adult stage. f-g) Specimen DO1/U-113; (f) longitudinal section; (g) transverse section. h) Specimen DO1/U-130, transverse section. i-j) Specimen DO1/U-136; (i) longitudinal section; (j) transverse section. k) Specimen DO1/U-146, transverse section of a young specimen. l-m) Specimen DO1/U-102; (I) microstructure of a septum showing mesoplasm organized in fascicles of fibers and fibronormal stereoplasm; (m) microstructure of dissepiments in longitudinal section, showing microgranular base and fibrous thickenings. Scale bar (close to a) for a-k $=5 \mathrm{~mm}$. Scale bars in 1 and $\mathrm{m}=100 \mu \mathrm{m}$. 


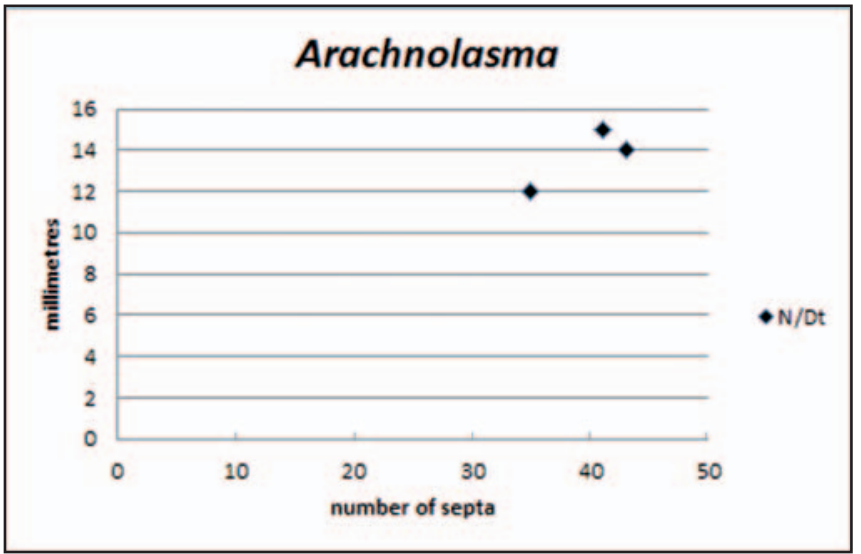

Figure 7. Plot of tabularium diameter (Dt) versus number of septa (N) in Arachnolasma sp. $(\mathrm{n}=3)$.

and counter septa are connected with the median lamella of the axial structure (Fig. 8a), which is small (diameter between 3 and $7 \mathrm{~mm}$ ) and composed of a thick median lamella, some short radial lamellae and many concentric tabulae. The dissepimentarium is composed of inosculate to angulate and herring-bone dissepiments. Some regular dissepiments occur also in the inner rows. They are long to globose and show a moderate inclination in longitudinal section.

The tabulae are mainly complete, but divided in two parts: axial tabulae are conical, steeply declined to the periphery, more markedly in the external part (Fig. 8b). They are bent to become almost horizontal in the periphery of the tabularium. Some small tabellae reinforce the boundary with the dissepimentarium.

The septa show two secretion phases. The mesoplasm is granulofibrous, organized in fascicles and the stereoplasm is fibronormal (Fig. 8d).
Remarks. The specimens identified as Arachnolasma sp. shows the typical axial structure of this genus, which differs from that of Dibunophyllum in being smaller, with a more conspicuous median lamella, and tabulae more complete and less declined to the periphery in the outer zone of the tabularium. The dimensions of the Tindouf specimens are similar to those of A. cylindricum Yu, 1934 but their fragmentary preservation prevents a precise specific identification.

\section{Family Palaeosmiliidae Hill, 1940}

Genus Palaeosmilia Milne-Edwards \& Haime, 1848

Diagnosis (Modified from Semenoff-Tian-Chansky, 1974). Solitary corals with numerous septa radially disposed; long minor septa; some major septa reach the axis. The cardinal fossula is narrow and reaches the axis. Incomplete tabulae disposed in two series. An axial series composed of globose tabellae, with the axial zone slightly depressed, and a periaxial series composed of convex tabellae that may be declined to the dissepimentarium. Numerous, small, regular dissepiments that may be replaced in the periphery by transeptal and/or naotic dissepiments. The microstructure is composed of a lamellar wall and fibrous septa. The peripheral part of the septa (dissepimentarium) is trabecular, but the inner zone of the septa (tabularium) is composed of fibers with waterjet disposition.

Palaeosmilia murchisoni Milne-Edwards \& Haime, 1848 (Figs 9, 10a)

Material. 4 specimens (DO1/U-29, 150, 152, 153); 4 transverse and 1 longitudinal thin sections.
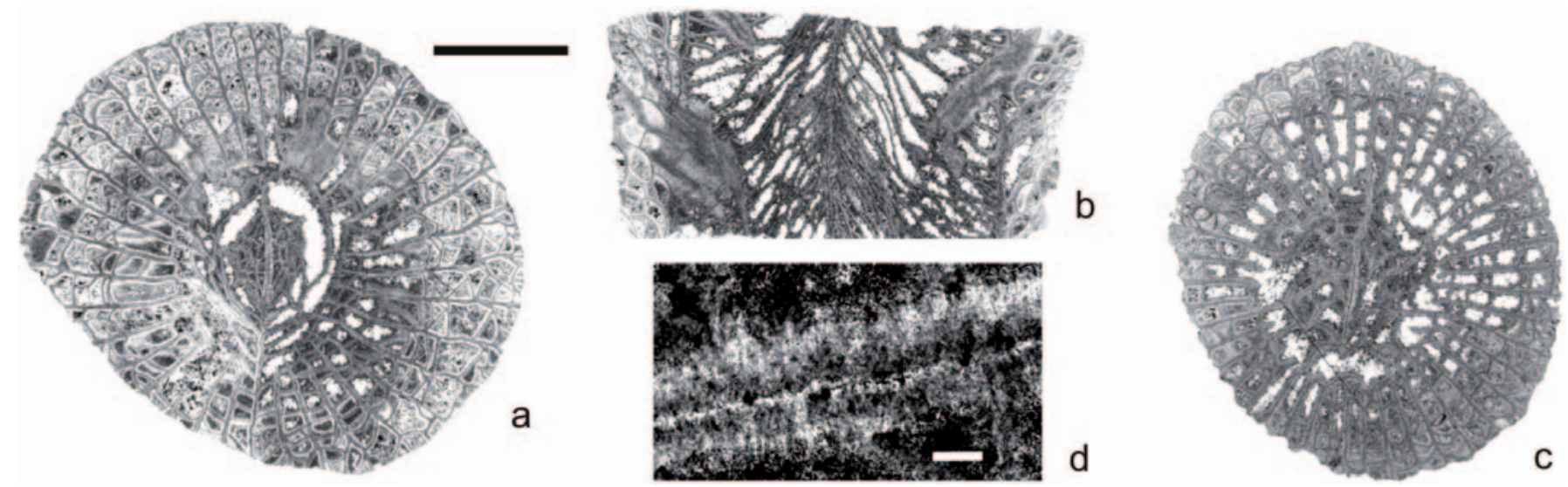

Figure 8. Arachnolasma sp. a-b) Specimen DO1/U-64; (a) transverse section; (b) longitudinal section. c) Specimen DO1/U-86, transverse section. d) Specimen DO1/U-64, microstructure of one septum, showing partly recystallized fibrous mesoplasm and fibronormal stereoplasm. Scale bar for a-c $=5 \mathrm{~mm}$. 3. Scale bar in $\mathrm{d}=100 \mu \mathrm{m}$. 


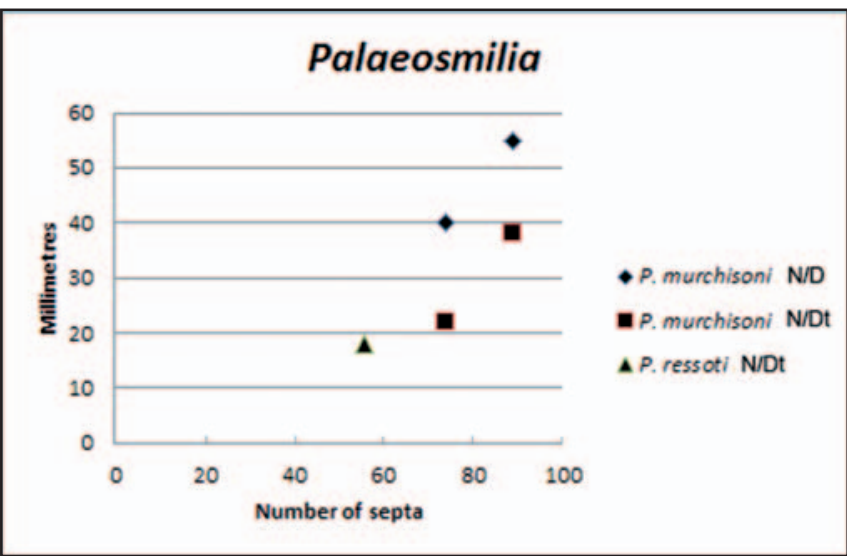

Figure 9. Plot of corallite diameter (D) and tabularium diameter (Dt) versus number of septa $(\mathrm{N})$ in Palaeosmilia murchisoni $(\mathrm{n}=4)$ and $P$. ressoti $(\mathrm{n}=1)$.

Location, horizon and age. From the plain to the south of the Djebel Ouarkziz escarpment, $10 \mathrm{~km}$ west of the road from Zag to Assa, Tindouf Basin, S. Morocco. Biostrome (bed U), upper member, Djebel Ouarkziz Fm. early Bashkirian.

Diagnosis (after Semenoff-Tian-Chansky, 1974). Solitary, turbinate to cylindrical, more or less curved Palaeosmilia that may reach large size $(10 \mathrm{~cm}$ in diameter). A large number of septa (typically 70-90) reach the axis. Narrow fossula that reaches the axis, where it gets wider. Long minor septa that reach $1 / 2$ to $2 / 3$ of the radius of the coral. Axial tabulae incomplete forming a central dome with a depressed axial zone. Lamellar wall and totally fibrous septa without discontinuity between the mesoplasm and stereoplasm. The septa may be trabecular, at least in part. Stereoplasmatic thickenings occur on thick dissepiments.

Description. Large, trochoid solitary corals. The alar diameter varies from 40 to $55 \mathrm{~mm}$; the tabularium diameter varies from 22 to $38 \mathrm{~mm}$ (Fig. 9). The external wall shows transverse wrinkles. The wall is thin and smooth, mostly eroded in our specimens. Locally, it may be somewhat thickened.

The dissepimentarium is composed of 10 to 20 rows of dissepiments. The outer rows may be composed of transeptal (lonsdaleoid) and/or naotic dissepiments. The inner rows are composed of interseptal, mainly regular, but in some cases crossed or angulate dissepiments. Distance between dissepiments of the same interseptal loculum is larger in the outer rows than in the inner rows. The width of the dissepimentarium varies from $1 / 2$ to $1 / 3$ of the radius.

Major septa are very long, all reaching the axial zone. They are straight in the tabularium, but they may be slightly sinuous in the dissepimentarium. Their number varies from 74 to 89 (Fig. 9). The cardinal septum is shortened in a long and narrow fossula, slightly expanded in the axial zone. The minor septa are also long, reaching approximately $1 / 2$ the length of the major septa.

The longitudinal sections show two series of tabulae: the outer series is composed of complete tabulae declined towards the periphery; the inner series is composed of incomplete tabulae having a domical form, but depressed in the axial zone.

The wall microstructure is lamellar, with lamellae piled up forming apparently fibers. The septa are fibrous. The outer parts of the septa are composed of trabeculae that are not strongly differentiated, but the inner zones of the septa are composed of fibers with water-jet disposition (see Semenoff-Tian-Chansky, 1974; fig. 61). The boundary between the trabecular and water-jet structures approximately coincides with the boundary between the dissepiments and tabulae. In transverse section the trabeculae are not conspicuous because they are disposed almost horizontal.

Remarks. Semenoff-Tian-Chansky (1974) distinguished four morphotypes of $P$. murchisoni: Palaeosmilia murchisoni forma murchisoni; P. murchisoni forma stutchburyi; P. murchisoni forma vesiculosa and $P$. murchisoni forma junctiseptata. These morphotypes seem to be related to the size of the coral and not related to stratigraphy or biogeography. Our specimens fit well with the very variable features described by Hill (1938), Semenoff-Tian-Chansky (1974) and Vuillemin (1990). Detailed synonymies can be found in these cited papers.

\section{Palaeosmilia ressoti Menchikoff \& Hsu, 1935}

(Figs 9, 10b)

Material. One single specimen (DO1/U-151); 1 transverse section.

Location, horizon and age. From the plain to the south of the Djebel Ouarkziz escarpment, $10 \mathrm{~km}$ west of the road from Zag to Assa, Tindouf Basin, S. Morocco. Biostrome (bed U), upper member, Djebel Ouarkziz Fm. early Bashkirian.

Description. Fragment of a trochoid coral; the outer wall is eroded and the apex is lost. The tabularium diameter is $18 \mathrm{~mm}$ and the number of septa is 56 (Fig. 9). The septa are long, and transected in the outer part by lonsdaleoid dissepiments. The outer part of the septa shows irregular thickenings and thinings. The inner part is more regular and shows progressive thinning to the axis. The septa do not reach the axis. They leave a free area of about $1 / 3$ of the tabularium diameter (Fig. 10b).

Lonsdaleoid dissepiments form a wide band in the external part of the dissepimentarium. The inner part is composed of interseptal, regular dissepiments. 

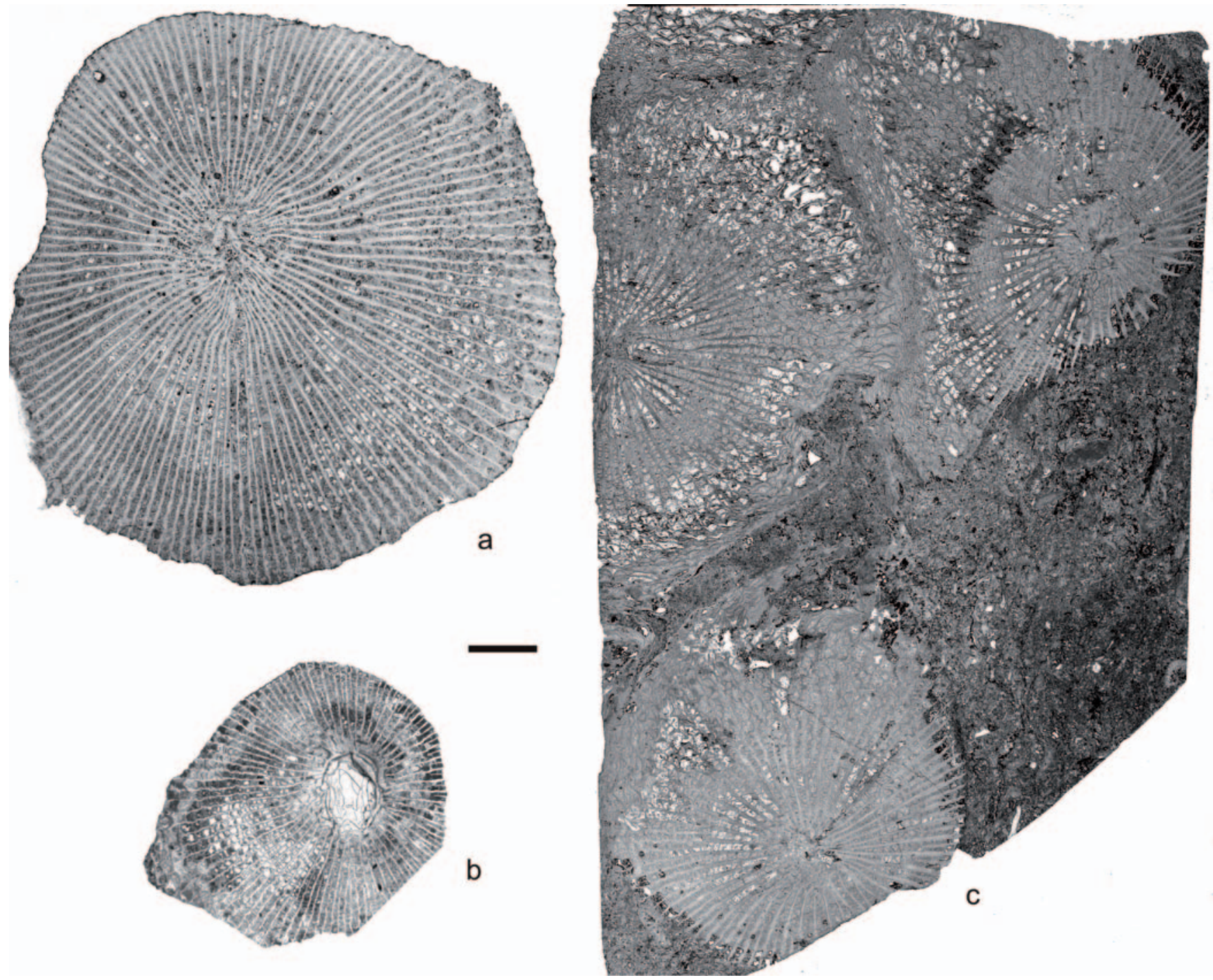

Figure 10. a) Palaeosmilia murchisoni, specimen DO1/U-150, transverse section. b) Palaeosmilia ressoti, specimen DO1/U-151, transverse section. c) Palastraea regia, specimen DO1/U-26, transverse section of a fragment of colony. Scale bar for a-c $=5 \mathrm{~mm}$.

Microstructure is typical for the genus, showing trabecular septa in the dissepimentarium that progressively pass to fibrous water-jet in the tabularium.

Remarks. Palaeosmilia ressoti is distinguished from P. murchisoni by its smaller size (tabularium diameter below $20 \mathrm{~mm}$ versus above $20 \mathrm{~mm}$ in $P$. murchisoni), fewer number of septa (below 60 versus above 70 in $P$. murchisoni) for corallites of similar diameter (Fig. 9) and more open axial region.

\section{Genus Palastraea McCoy, 1851}

Diagnosis (after Hill, 1981). Cerioid, asteroid or aphroid Palaeosmilia.

Palastraea regia (Phillips, 1836)

(Figs 10c, 11)
Material. One fragment of one colony (DO1/U-26); 3 transverse thin sections.

Location, horizon and age. From the plain to the south of the Djebel Ouarkziz escarpment, $10 \mathrm{~km}$ west of the road from Zag to Assa, Tindouf Basin, S. Morocco. Biostrome (bed U), upper member, Djebel Ouarkziz Fm. early Bashkirian.

Description. Colonial coral with corallites having alar diameter from 24 to $32 \mathrm{~mm}$ and tabularium diameter from 11 to $14 \mathrm{~mm}$.

The zones between corallites usually show broken structures because of compression (Fig. 10c). The dissepimentarium is composed of 9 to 15 rows of interseptal, regular, thin dissepiments in the inner zone, which change to lonsdaleoid and naotic in the outer zone. The inner row of dissepiments is not thickened. Major 
septa are long, mainly thin and straight. They are somewhat thickened in the tabularium (spindle-shaped). In the axial zone they may be somewhat sinuous and thinner. The number of septa varies between 39 and 52 (Fig. 11). The cardinal septum is shorter and it is located in a narrow fossula. The minor septa are long and thin, $1 / 2$ the length of major septa.

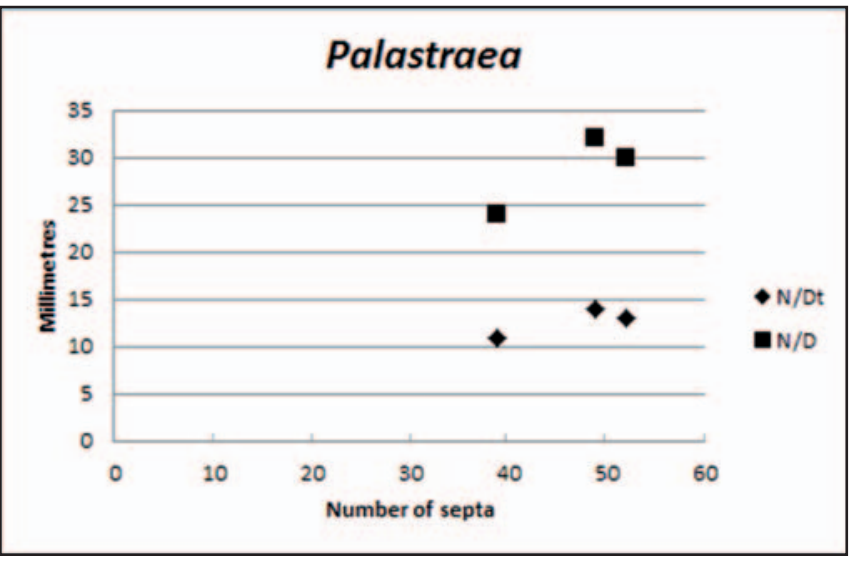

Figure 11. Plot of corallite diameter (D) and tabularium diameter (Dt) versus number of septa $(\mathrm{N})$ in Palastraea regia $(\mathrm{n}=1)$.

The wall microstructure is fibrous, the fibers being disposed in fascicles. The septa are fibrous. The fibers are organized in sub-horizontal trabeculae in the dissepimentarium, but they do not occur in the tabularium. The thickenings of the dissepimentarium are also fibrous.

Remarks. The morphological and microstructural features of the studied specimens are similar to those of the genus Palaeosmilia. However, the latter is solitary and the massive colonial specimens with astreoid to aphroid habit are included in the genus Palastraea (see above). The alar diameters of the corallites of Palastraea from Tindouf fit well with the variability of Palastraea regia (Said, 2005). The only specimen shows a broken outer zone of corallites.

Family Lithostrotionidae d'Orbigny, 1852

Genus Siphonodendron McCoy, 1849

Diagnosis (after Poty, 1981). Fasciculate coral, with corallites having styliform columella. Major septa variable in length, that may reach the columella or not. Minors more-or-less developed, reduced to the dissepimentarium or penetrating slightly in the outer tabularium. Dissepimentarium well developed, composed of regular dissepiments, absent in the very small species. Complete or somewhat divided, conical tabulae. They form a channel close to the dissepimentarium. Lateral, nonparricidal budding, except in some rare species, in which it may be both lateral and peripheral and parricidal.

Siphonodendron tindoufense sp. nov.

(Figs 12, 13)

\section{Synonymy.}

? 1955 Lithostrotion junceum; Fabre, p. 8.

? 1985 Siphonodendron sp. A; Semenoff-Tian-Chansky, p. 377.

Derivatio nominis. The name of the species refers to the Tindouf Basin, in which it has been recorded.

Holotype. Specimen DO1/U-8; rest of the specimens collected in the same bed are regarded as paratypes.

Type locality, horizon and age. From the plain to the south of the Djebel Ouarkziz escarpment, $10 \mathrm{~km}$ west of the road from Zag to Assa, Tindouf Basin, S. Morocco. Biostrome (bed U), top beds of upper member, Djebel Ouarkziz Fm.; early Bashkirian.

Material. 16 colonies (DO1/U-1, 3-17), plus some branches related to other coral specimens; 27 transverse and 13 longitudinal thin sections.

Diagnosis. Siphonodendron having corallites with 3 to $5.5 \mathrm{~mm}$ in diameter, 15 to 21 major and minor septa, discontinuous columella, complete, flat to slightly conical tabulae, and a single row of dissepiments.

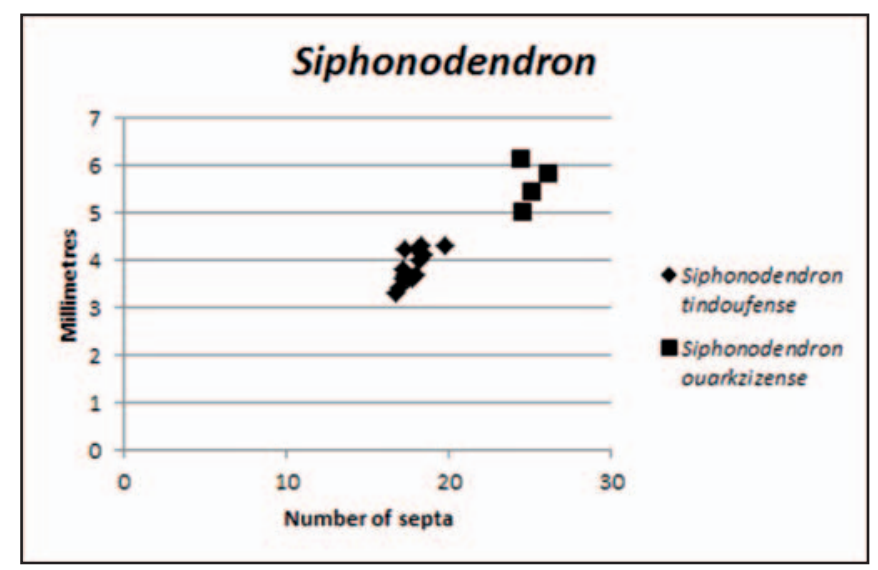

Figure 12. Plot of corallite diameter ( $\mathrm{mm})$ versus number of septa in Siphonodendron tindoufense sp. nov. $(\mathrm{n}=16)$ and $S$. ouarkzizense sp. nov. $(\mathrm{n}=4)$.

Description. Phaceloid coral that built large colonies up to $1.5 \mathrm{~m}$ in diameter and $50 \mathrm{~cm}$ high. Corallites are small, reaching between 3 and $5.5 \mathrm{~mm}$ in diameter in adult stage. The mean diameter for each colony varies between 

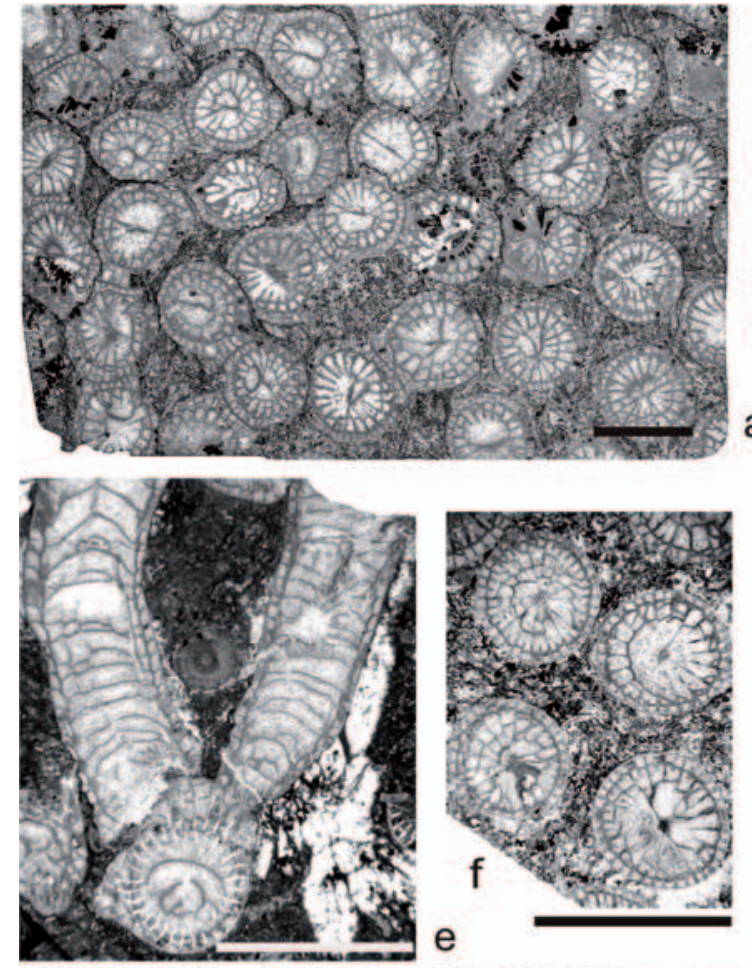
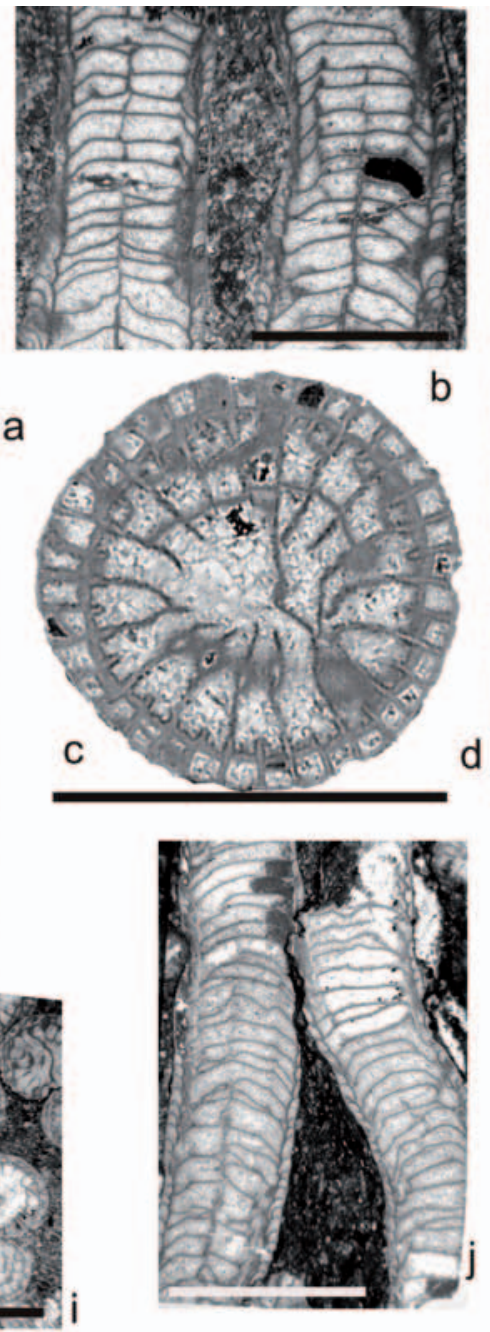
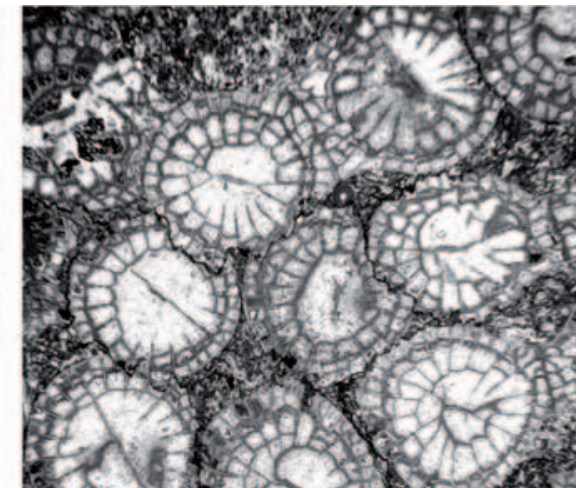

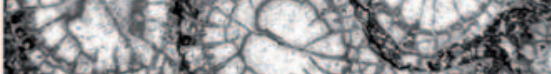

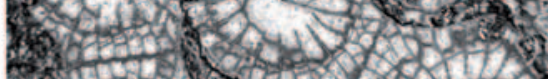
in 070 .

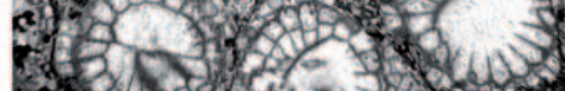
d

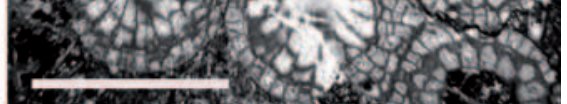
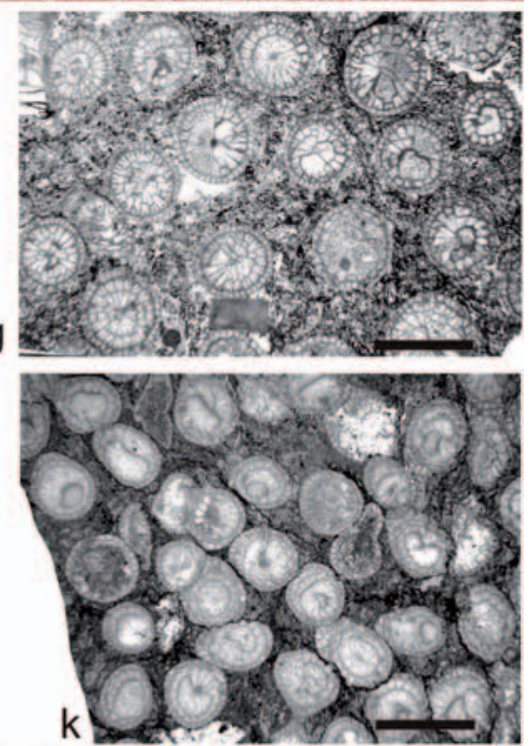
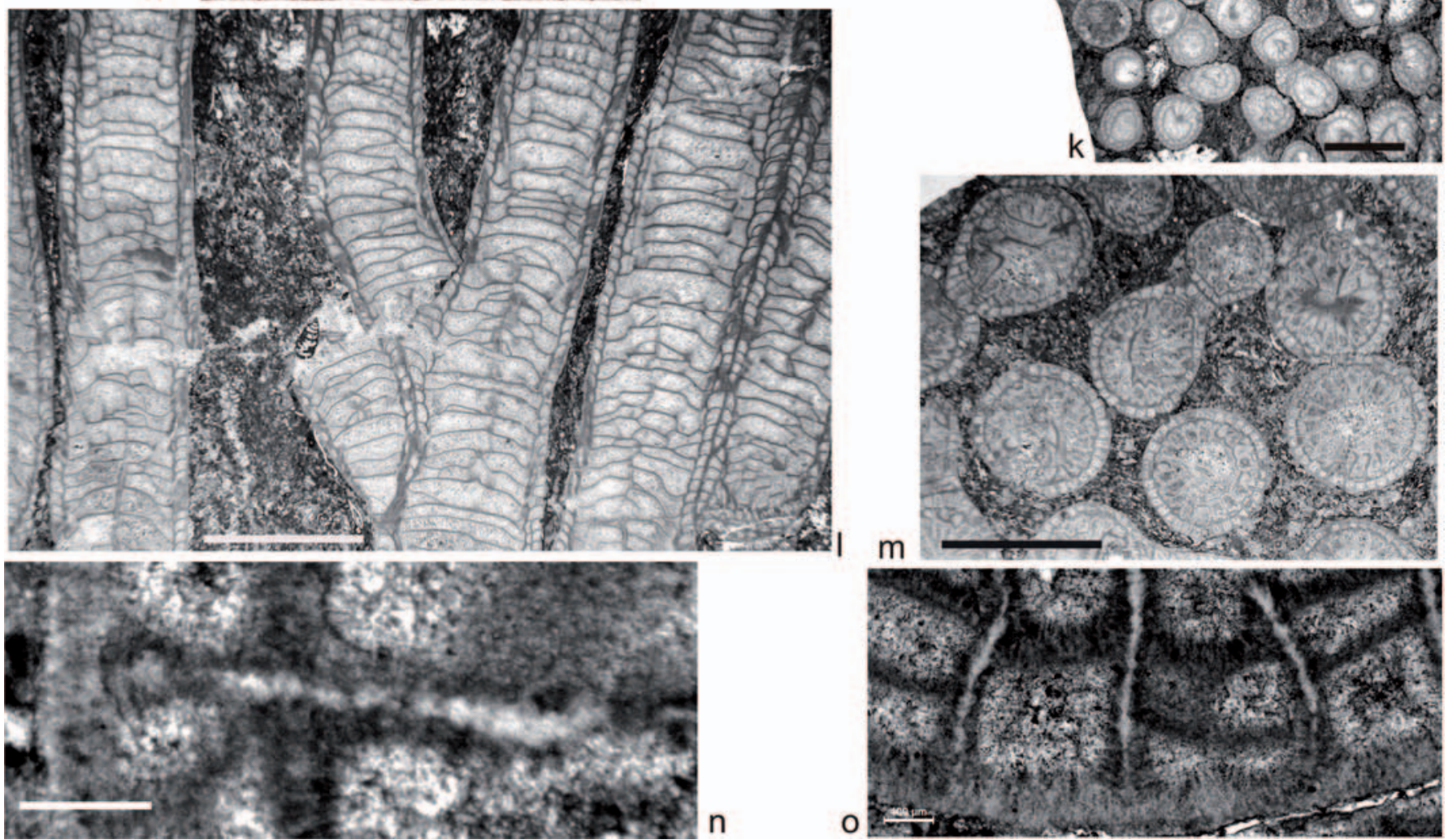
3.4 and $4.3 \mathrm{~mm}$ (Fig. 12). The tabularium diameter varies between 2 and $4 \mathrm{~mm}$. The mean for each colony varies between 2.5 and 3.6. Corallites are always densely packed (Figs 13a, 13d, 13f, 13g, 13i, 13k, 13m).

The wall is thin and smooth and frequently lacking, even in specimens collected in growth position, because of stylolitic seams. The major septa are thin, somewhat thickened in the external border of the tabularium and variable in length; in some instances they reach the columella, but usually their length is about one-half to two-thirds of the radius. Their number varies from 15 to 21 in adult stages (Fig. 12) and the mean of each colony varies between 17 and 19.8. The minor septa are relatively short, 1/4 length of major septa, mostly confined to the dissepimentarium but appearing as crests on the outer tabularium wall (Fig. 13c). The axial columella is a single lamina, variable in thickness and discontinuous (Figs 13b, $13 \mathrm{e}, 13 \mathrm{~h}, 13 \mathrm{j}, 13 \mathrm{l})$. In some specimens most transverse sections of corallites do not show a columella, but in most colonies, at least two-thirds of the sections show one. In longitudinal section the columella displays interruptions and variations in thickness, but is always quite thin.

The dissepimentarium is simple, composed of a single row of small dissepiments that are globose in longitudinal section, rarely showing some additional dissepiments that never form a second row (Figs 13h, 131). The tabularium is wide, varying between 2 and $4 \mathrm{~mm}$ in diameter. The tabulae are flat mesa-shaped or slightly conical in the axial zone and curved downwards near the dissepimentarium. They number 15-22/10 $\mathrm{mm}$.

The microstructure is completely fibrous. The wall shows large fibres perpendicular to the border of the corallite (Figs 13n, 13o). The septa are composed of fascicles of fibres, with occasional fibrous thickenings (Figs 13n, 13o).

Remarks. We assume that the new species is the same as that which Fabre (1955) called Lithostrotion junceum and Semenoff-Tian-Chansky named Siphonodendron sp. A, but we cannot confirm this, because neither author described or figured any specimens. We base our assumption on the dominance of this species in the same biostrome that they referred to and developed at the same stratigraphic level, and the small size of corallites that could be compared with the smallest species of the genus, but distinguished from $S$. junceum by the presence of a single row of dissepiments.

Semenoff-Tian-Chansky (1985) and Legrand-Blain et al. (1989) indicate the presence of the same species in equivalent beds in the Reggan, Ahnet and Taoudenni basins. If it was confirmed, it could form an important marker horizon for the base of the Bashkirian in the Carboniferous basins of the Sahara.

Siphonodendron tindoufense sp. nov. shows similar dimensions and number of septa as the type species, $S$. pauciradiale, and indeed, affinity with this species was suggested in Legrand-Blain et al. (1989, p. 224). However, it differs from the latter in having a discontinuous columella, mainly flat tabulae and always bearing a single row of dissepiments.

\section{Siphonodendron ouarkzizense sp. nov.} (Figs 12, 14)

Derivatio nominis. The name of the species refers to the Ouarkziz Range, in which it has been recorded.

Holotype. Specimen DO1/U-18, rest of the specimens collected in the same bed are regarded as paratypes.

Type locality, horizon and age. From the plain to the south of the Djebel Ouarkziz escarpment, $10 \mathrm{~km}$ west of the road from Zag to Assa, Tindouf Basin, S. Morocco. Biostrome (bed U), top beds of upper member, Djebel Ouarkziz Fm.; early Bashkirian.

Material. 4 colonies and many free corallites coming from them (DO1/U-18, 19, 20, 21); 8 transverse and 5 longitudinal thin sections.

Diagnosis. Siphonodendron having corallites with 4 to $7 \mathrm{~mm}$ in diameter, 23 to 28 major and minor septa,

Figure. 13. Siphonodendron tindoufense. a-d) Specimen DO1/U-8 (holotype); (a) transverse section, general view of a part of the colony; (b) longitudinal section, detail of two corallites showing discontinuous axial plate; (c) transverse section, detail of one corallite; (d) transverse section, detail showing corallites with and without axial plate; (e) specimen DO1/U13 (paratype) showing lateral budding. f-g) Specimen DO1/U-12 (paratype); (f) transverse section showing a detail of four corallites; (g) general view of a portion of the colony showing high packing of corallites. h-i) Specimen DO1/U14 (paratype); (h) longitudinal section of one corallite showing that the single row of dissepiments may rarely present a second superimposed dissepiment; (i) general view of a portion of the colony showing quite small corallites. j-k) Specimen DO1/U-15 (paratype); (j) longitudinal section showing variability in the axial plate; (k) transverse section of a portion of the colony that show the smallest corallite size in the collection. l-m) Specimen DO1/U-1 (paratype); (l) longitudinal section showing lateral budding; (m) transverse section of the colony showing the largest corallites in the collection. n-o) Specimen DO1/U-12 (paratype), microstructure; (n) detail of one septum showing trabecular mesoplasm and fibronormal stereoplasm; fibrous wall left; (o) Detail of several septa showing same features as "n" plus fibrous thickenings on dissepiments. Scale bars in $\mathrm{a}-\mathrm{m}=5 \mathrm{~mm}$. Scale bars in $\mathrm{n}$ and $\mathrm{o}=100 \mu \mathrm{m}$. 
discontinuous columella, complete, mesa-shaped to conical tabulae and one single row of dissepiments.

Description. Phaceloid colonies. Most studied specimens were fragmented (Fig. 14g), but the colonies reach at least $50 \mathrm{~cm}$ in diameter and $50 \mathrm{~cm}$ high. Corallites are small, reaching between 4 and $7 \mathrm{~mm}$ in diameter in adult stage. The mean diameter for each colony varies between 5 and $6.1 \mathrm{~mm}$ (Fig. 12). The tabularium diameter varies between 3.5 and $5.5 \mathrm{~mm}$. The mean for each colony varies between 4.2 and $5.1 \mathrm{~mm}$.

The wall is thin and smooth. The septa are thin and variable in length; sometimes they are somewhat thickened in the external border of the tabularium; in some instances they reach the columella, but usually their length is about one-half to three-fourths of the radius. The number of major septa varies from 23 to 28 in adult stages (Fig. 12) and the mean of each colony varies between 24.5 and 26.2. Minor septa are much shorter in length, 1/4 the length of major septa, and extend into the outer tabularium (Figs 14a, 14f). The axial columella is a single lamina, variable in thickness and discontinuous. In longitudinal section it shows interruptions and variations in thickness (Figs 14b-d).

The dissepimentarium is simple, composed of a single row of small dissepiments that are globose in longitudinal section. The tabularium is wide, varying between 3.5 and $5.5 \mathrm{~mm}$ in diameter. The tabulae are flat, mesa-shaped to conical in the axial zone and curved downwards near
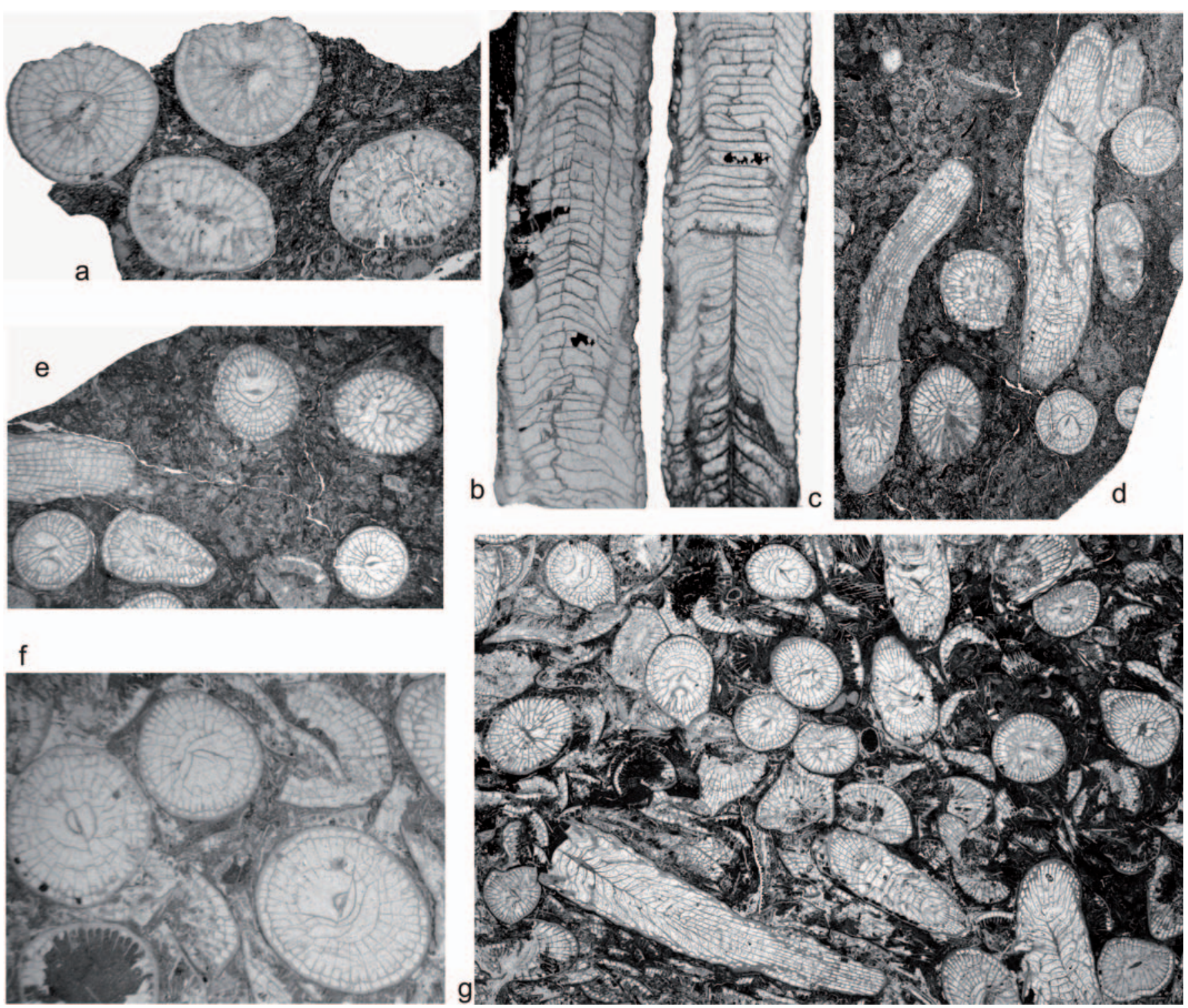

Figure 14. Siphonodendron ouarkzizense. a-c) Specimen DO1/U-18 (holotype); (a) transverse section of a small part of the colony; (b-c) longitudinal sections showing the discontinuous axial plate. d-e) Specimen DO1/U-19 (paratype), parts of the colony showing transverse and longitudinal sections. f-g) Specimen DO1/U-21 (paratype); (f) transverse section with detail of several corallites, $\mathrm{x} 4$; (g) general view of the colony showing high degree of fragmentation. Scale bars $=5 \mathrm{~mm}$. 
the dissepimentarium. They number 18-24/10 $\mathrm{mm}$. When the columella is absent over a long interval, they form a general convex shape.

The microstructure is identical to that described in Siphonodendron tindoufense.

Remarks. This species show many similarities with S. tindoufense, and it is clearly related to it. They share the same type of discontinuous and variable columella, the single row of dissepiments, identical microstructure and the same shape of the tabulae that distinguish them from other Mississippian Siphonodendron species from the western Palaeotethys. However, the differences between them are sufficient to erect a new species. The number of septa is higher and there is no overlap between the two species. The diameter is also larger with very little overlap (Fig. 12), the columella reaches a much greater thickness in some corallites of $S$. ouarkzizense and the tabulae may be also more typically conical in this species.

Siphonodendron ouarkzizense has a similar number of septa as S. martini (Milne-Edwards \& Haime, 1851), but the alar diameter is closer to $S$. irregulare, sharing with the latter the presence of a single row of dissepiments. But the presence of a discontinuous columella in $S$. ouarkzizense is sufficient to distinguish it from both of these species.

No references to this species have been made in any previous published work in the Tindouf Basin. Thus, we conclude that either it is not present in the eastern (Algerian) part of the Djebel Ouarkziz or it went unnoticed because of the fewer number of colonies in comparison with $S$. tindoufense.

\section{Genus Diphyphyllum Lonsdale, 1845}

Diagnosis (after Poty, 1981). Fasciculate coral with corallites lacking a columella and peripheral, parricidal increase. Short major septa. Minor septa restricted to the dissepimentarium or crossing slightly the inner border. Simple regular dissepiments. Tabulae usually divided; axial tabulae flat, horizontal and having curved borders to join the subjacent tabulae; periaxial tabulae flat, horizontal or somewhat declined to the dissepimentarium. Small cardinal fossula present.

\section{Diphyphyllum maximum Poty, 1981}

(Figs 15-16)

Material. 1 colony (DO1/U-2); 3 transverse and 3 longitudinal thin sections.

Location, horizon and age. From the plain to the south of the Djebel Ouarkziz escarpment, $10 \mathrm{~km}$ west of the road from Zag to Assa, Tindouf Basin, S. Morocco. Biostrome (bed U), upper member, Djebel Ouarkziz Fm. early Bashkirian.

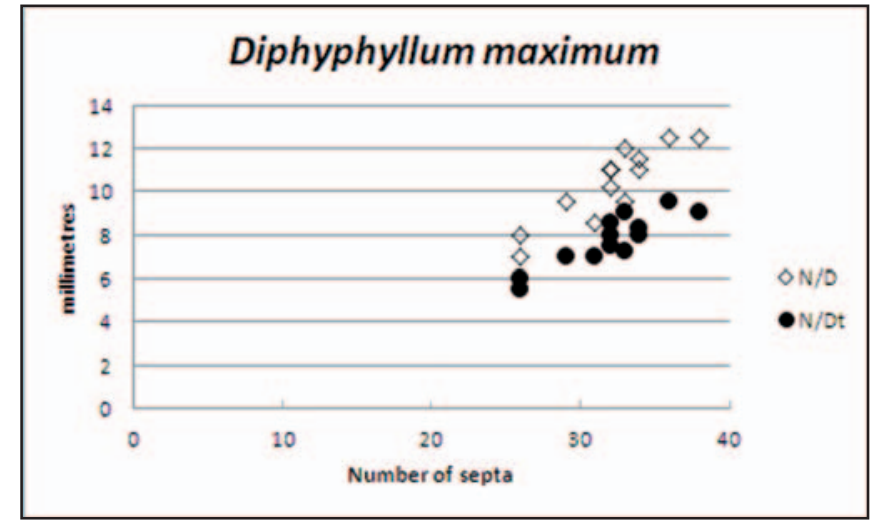

Figure 15. Plot of corallite diameter (D) and tabularium diameter (Dt) versus number of septa $(\mathrm{N})$ in Diphyphyllum maximum $(\mathrm{n}=1)$.

Description. One single phaceloid colony showing large corallites, from 9 to $12.5 \mathrm{~mm}$ in diameter and 7 to 10 $\mathrm{mm}$ in tabularium diameter. There are 30 to 38 major septa in adult corallites (Fig. 15). They are thin and irregular, undulose to zig-zag, rarely carinate in the dissepimentarium and somewhat thickened in the tabularium (Figs 16a-d). They leave an axial space free of septa that is 2 to 4 $\mathrm{mm}$ in diameter. The major septa are longer in the upper surface of the tabulae. Minor septa are located in the dissepimentarium (thin) and in the peripheral part of the tabularium (thickened). The dissepimentarium is relatively narrow, composed of 3 to 5 rows of interseptal, regular dissepiments. They are globose and moderately declined towards the axis. The tabulae are mostly complete, but show some reinforcing tabellae in the peripheral part. They are flat and horizontal in the axial part, curved to almost vertical and touching the subjacent tabula in the border of the axial zone and declined towards the dissepimentarium at the periphery (Figs 16e-f).

The microstructure of the septa is composed of one single phase of secretion, with some stereoplasmatic thickenings. The septa are trabecular in the dissepimentarium and in most of the tabularium (Figs $16 \mathrm{~g}, \mathrm{~h}$ ), being fibrous with water-jet distribution in the inner border. Wall, dissepiments and tabulae are fibrous.

Remarks. The specimen collected in Tindouf shows identical features as the type specimen collected in Belgium (Poty, 1981). It shows also some similarities with the coral identified as Tizraia cf. Diphyphyllum carinatum by Fedorowski \& Bamber (2012) from Arctic Canada, that we think should be not included in Tizraia but in Diphyphyllum. The species Diphyphyllum carinatum Gorsky (1951) from Novaya Zemlya shows stronger development of carinae and smaller dimensions than the Tindouf specimens. Interestingly, both taxa occur in the early Bashkirian. 

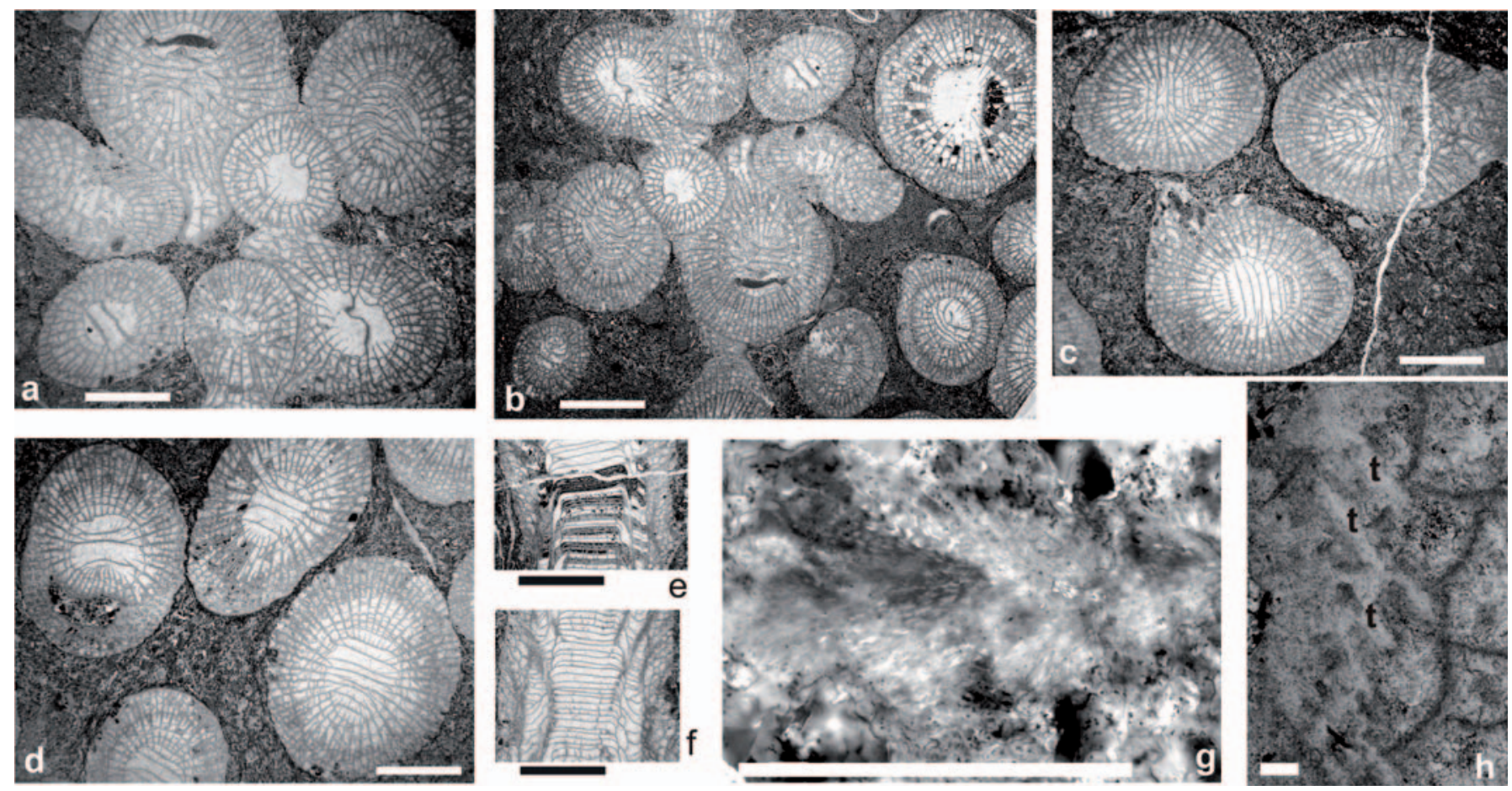

Figure 16. Diphyphyllum maximum. Specimen DO1/U-2. a-d) Transverse sections of different parts of the colony; e-f) Longitudinal sections; g) Detail of trabeculae in one septum; h) Longitudinal section showing a tangential view of one septum composed of trabeculae $(\mathrm{t})$. Scale bars in $\mathrm{a}-\mathrm{f}=5 \mathrm{~mm}$. Scale bars in $\mathrm{g}$ and $\mathrm{h}=100 \mu \mathrm{m}$.

Family Axophyllidae Milne-Edwards \& Haime, 1851

Genus Axophyllum Milne-Edwards \& Haime, 1850

Diagnosis (after Semenoff-Tian-Chansky, 1974). Solitary coral, wall usually festooned. Septa of two orders, thick in the periphery where they are interrupted in adult stage by large transeptal dissepiments. Residual septal crests occur usually on the surface of the dissepiments. Fossula absent or weakly developed. Axial structure formed by thickened, irregular and anastomosed radial lamellae, crossed by a median lamella, whose outline in transverse section are not clear in some instances, because of their irregularity and the junction of the radial lamellae. Long dissepiments in longitudinal section. Tabulae rising to the axis, horizontal or declined to the pericolumellar zone. Microstructure of the wall is lamellar. The festoons are composed of piled lamellae organized in fans in transverse section. Septa with fibrous mesoplasm and lamellar stereoplasm.

\section{Axophyllum moroccoense sp. nov.}

(Figs 17, 18)

Derivatio nominis. The name of the species refers to the country where it has been sampled.

Holotype. Specimen DO1/U-80; rest of the specimens collected in the same bed are regarded as paratypes.
Type locality, horizon and age. From the plain to the south of the Djebel Ouarkziz escarpment, $10 \mathrm{~km}$ west of the road from Zag to Assa, Tindouf Basin, S. Morocco. Biostrome (bed U), top beds of upper member, Djebel Ouarkziz Fm.; early Bashkirian.

Material. 14 fragmentary specimens (DO1/U-16, 30$32,44,49,56,65,80,121,123-125,147) ; 20$ transverse and 5 longitudinal thin sections.

Diagnosis. Solitary coral being about $28 \mathrm{~mm}$ in diameter, 12 to $19 \mathrm{~mm}$ in tabularium diameter. 27 to 34 major septa that are interrupted by large lonsdaleoid dissepiments that form a wide dissepimentarium. Axial structure irregular, composed of a median lamella, a few radial lamellae and conical axial tabulae. Periaxial tabulae horizontal or somewhat declined to the periphery.

Description. Fragmentary, solitary, trochoid to ceratoid corals. Lacking an apex and most of the dissepimentarium. Only in three specimens was it possible to measure the diameter; in all cases $28 \mathrm{~mm}$. The tabularium diameter varies from 12 to $19 \mathrm{~mm}$ and the axial structure diameter varies from 6 to $9 \mathrm{~mm}$. The number of major septa varies from 27 to 34 (Fig. 17). They are long, reaching almost the axial structure. Major septa are thick in the tabularium, tapering slightly axially, but thin in the dissepimentarium. They are interrupted by large lonsdaleoid dissepiments 


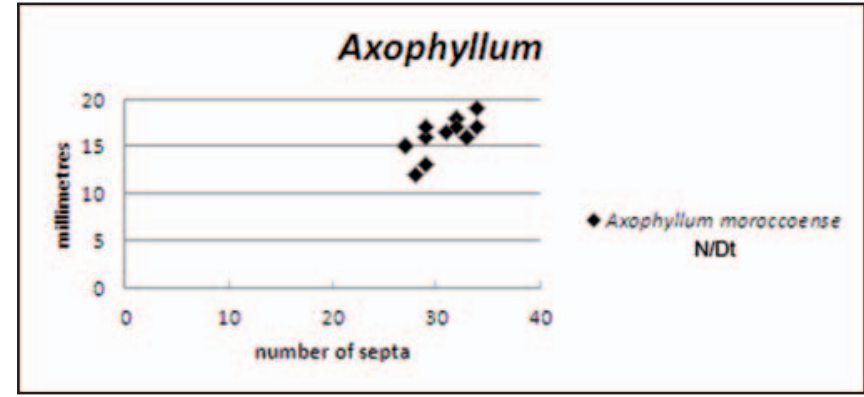

Figure 17. Plot of tabularium diameter (Dt) versus number of septa $(\mathrm{N})$ in Axophyllum moroccoense sp. nov. $(n=14)$.
(Figs 18a, 18c, 18e). Minor septa appear as short crests occurring in the external border of the tabularium and on inner dissepiments. The dissepimentarium is composed of one or two rows of very large lonsdaleoid dissepiments that are mostly eroded in our specimens (Figs 18e-f, 18h). In longitudinal section they are long and steeply declined towards the tabularium (Figs 18b, 18d, 18g).

The axial structure is extremely variable. The median lamella is always present, but it is irregular and in many cases not very conspicuous (Figs 18a, 18c). The radial lamellae are low in number ( 8 to 12 ), usually thick, short and irregular, but in some sections (they may differ in two sections of the same specimen) they are radial and show
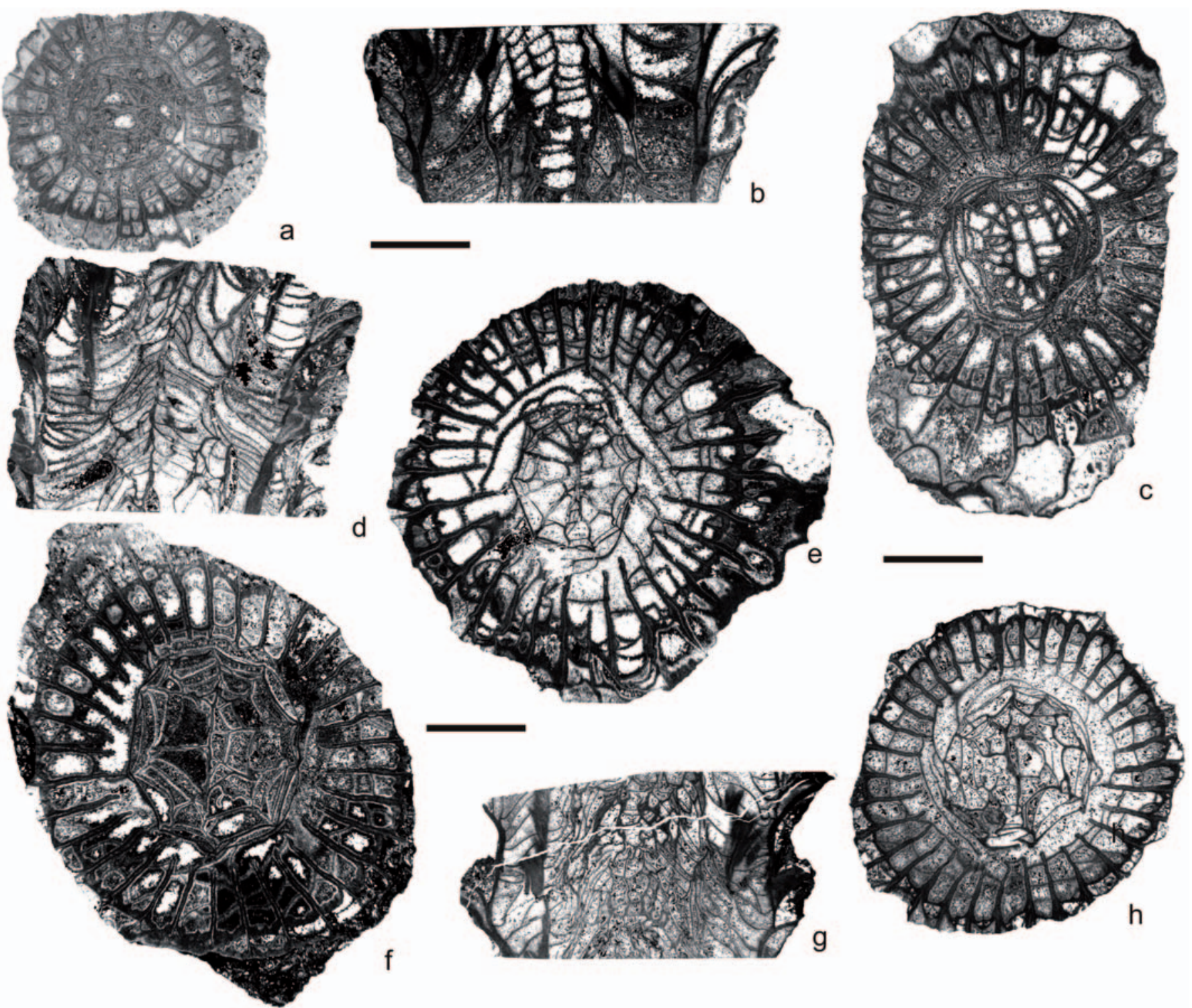

Figure 18. Axophyllum moroccoense. a-c) Specimen DO1/U-80 (holotype); (a) transverse section in young stage; (b) longitudinal section; (c) transverse section in adult stage; note the large lonsdaleoid dissepiments and the irregular axial structure. d-e) Specimen DO1/U-121 (paratype); (d) longitudinal section; (e) transverse section. f) Specimen DO1/U-56 (paratype), transverse section showing quite feeble axial structure. g-h) Specimen DO1/U-123 (paratype); (g) longitudinal section; (h) transverse section showing quite large axial structure. Scale bars for all figures $=5 \mathrm{~mm}$. 
some bifurcations (Figs 18f, 18h). In longitudinal section the axial tabulae are mostly complete, showing some reinforcing tabellae. Their shape is conical to domical. The periaxial tabulae are concave and declined to the dissepimentarium (Figs 18b, 18d, 18g). Tabularium wall is conspicuous.

The microstructure is recrystallized in most specimens, but those that are partially preserved show a fibrous mesoplasm and lamellar stereoplasm. The wall, dissepiments and tabulae are also lamellar.

Remarks. The specimens from the Tindouf biostrome differ from all species of the A. kirsopianum group ( $A$. kirsopianum, A. pseudokirsopianum, A. mendipense, $A$. densum, etc.), because of the great development of the lonsdaleoid dissepimentarium. The type species $A$. expansum Milne-Edwards \& Haime, 1850 has a similar lonsdaleoid dissepimentarium and variable axial structure, but is smaller in size (14 versus $28 \mathrm{~mm}$ in diameter). The same difference is shown with A. lonsdaleiforme Salée, 1913 plus a wider lonsdaleoid dissepimentarium. Finally, A. vaughani Salée, 1913 shows also a wide lonsdaleoid dissepimentarium, but differs from the Moroccan specimens in having a smaller size and more regular axial structure.

\section{Genus Gangamophyllum Gorsky, 1938}

Diagnosis (after Semenoff-Tian-Chansky, 1974). Simple, conical coral with dissepimentarium comprising a peripheral sub-zone with large transeptal dissepiments. Dissepitheca that is reduced in the adult stages. Central zone is present in the form of a net without a median lamella in the centre. It is composed of thick radial lamellae and axial tabulae; it is irregular and less dense in the centre than in the periphery. In longitudinal sections, large dissepiments are steeply declined to the axis. Periaxial tabulae declined to the axis and slightly depressed. Axial structure composed of a group of radial lamellae thickened and interlaced with axial tabellae building a domal structure.

\section{Gangamophyllum sp.}

(Figs 19, 20a-d)

Material. 3 fragmentary specimens (DO1/U-42, 66, 77); 4 transverse and 3 longitudinal thin sections.

Location, horizon and age. From the plain to the south of the Djebel Ouarkziz escarpment, $10 \mathrm{~km}$ west of the road from Zag to Assa, Tindouf Basin, S. Morocco. Biostrome (bed U), upper member, Djebel Ouarkziz Fm. early Bashkirian.

Description. Fragments of solitary corals, lacking the apex, the calice, the external wall and most of the

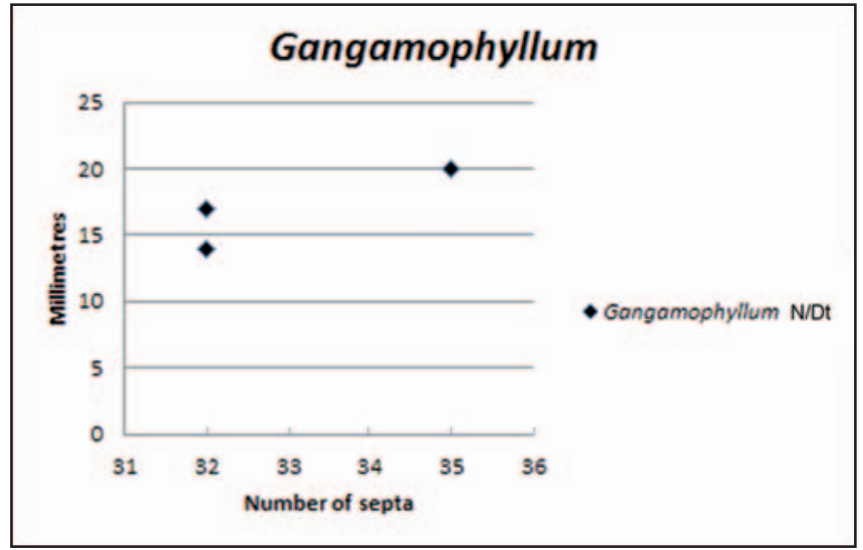

Figure 19. Plot of tabularium diameter (Dt) versus number of septa (N) in Gangamophyllum sp. $(n=3)$.

dissepimentarium (Figs 20a-d). The alar diameter is not measurable because of the absence of the complete dissepimentarium. The tabularium diameter varies between 14 and $20 \mathrm{~mm}$, the axial structure diameter varies between 7 and $11 \mathrm{~mm}$. There are 32 to 35 major septa (Fig. 19) which are thin in the dissepimentarium and thick in the tabularium. Their inner border may be curved and related to tabulae of the axial structure. Minor septa are reduced to crests on the inner rows of dissepiments. The axial structure is irregular. It lacks a median lamella, but is composed of 8 to 16 irregularly radial lamellae and some concentric tabulae that are more densely packed in the outer part of the structure (Fig. 20c).

The dissepiments are usually eroded, but there are lonsdaleoid dissepiments in the outer zones and one or two rows of interseptal dissepiments close to the tabularium (Fig. 20c). In longitudinal section the dissepiments are large, long and very steeply declined towards the tabularium. The tabulae are flat in the axial area, progressively declined to the periphery in the axial structure and flat to somewhat concave and slightly declined to the dissepimentarium in the periaxial zone (Figs 20b, d).

Remarks. The presence of lonsdaleoid dissepiments and an axial structure without a median lamella allow to identify the specimens as Gangamophyllum. But they are too fragmentary and intensely eroded to recognize them at specific level.

\section{Genus Axoclisia Semenoff-Tian-Chansky, 1974}

Diagnosis (modified from Semenoff-Tian-Chansky, 1974). Solitary coral with clisiophylloid axial structure, but having transeptal dissepiments of the second order. The tabulae are convex and they are declined to the dissepimentarium. 
Axoclisia sahariense sp. nov.

(Figs 20e-k, 21)

Derivatio nominis. The name of the species refers to its presence in the Western Sahara.

Holotype. Specimen DO1/U-59; rest of the specimens collected in the same bed are regarded as paratypes.

Type locality, horizon and age. From the plain to the south of the Djebel Ouarkziz escarpment, $10 \mathrm{~km}$ west of the road from Zag to Assa, Tindouf Basin, S. Morocco. Biostrome (bed U), top beds of upper member, Djebel Ouarkziz Fm.; early Bashkirian.

Material. 3 fragmentary specimens (DO1/U-35, 59 and 76); 7 transverse and 3 longitudinal thin sections.

Diagnosis. Solitary coral, 19 to $24 \mathrm{~mm}$ in diameter and 29 to 33 major septa. Clisiophylloid axial structure with well-developed median lamella. Wide lonsdaleoid dissepimentarium composed of large dissepiments, long in transverse section. Conical axial tabulae and variable periaxial tabulae.

Description. Solitary coral, fragmentary and partially eroded. The alar diameter (reconstructed) is about 19 to 24 $\mathrm{mm}$. The tabularium diameter varies from 11.5 to $12.8 \mathrm{~mm}$ and the axial structure varies from 5 to $6 \mathrm{~mm}$. The wall is not preserved in our specimens. There are 29 to 33 major septa (Fig. 21) that are variably thickened in the tabularium and very thin when preserved in the dissepimentarium. Minor septa are discontinuous in part and reduced to small, thin crests on the dissepiments and in the outer tabularium. The outer tabularium wall shows a slight thickening, especially in the young stage (Figs 20e, 20i). The septa are interrupted by a broad dissepimentarium composed of large lonsdaleoid dissepiments that in longitudinal section are very steeply declined to the axis. The axial tabulae are conical and very densely packed in longitudinal section. The periaxial tabulae are horizontal to somewhat declined to the axis and sparsely distributed (Figs 20g, 20j).

The axial structure is composed of a thick median lamella that does not reach the boundary of the structure, numerous thin radial lamellae (c. 25) and abundant conical tabulae that in transverse section show a concentric distribution (9-10 rows). It is completely developed in late young stages (Figs 20e, 20i). The external border of the ovoid axial structure is well defined.

The microstructure is partly destroyed by diagenesis, but the fibrous water-jet structure of the septa is still identifiable in many portions of the coral (Fig. 20h).

Remarks. The original diagnosis of Axoclisia given by Semenoff-Tian-Chansky (1974) included only corals having transeptal second order dissepiments. We do not find any inconvenience to include in the same genus forms having also transeptal dissepiments of the first order. Axoclisia is an extremely scarce genus. It was described by Semenoff-Tian-Chansky (1974) based on a single specimen. Subsequently, it has been described in SW Spain (Rodríguez et al., 2001, p. 62-64; pl. 2, figs 13-15), represented by two specimens in the Tizra Formation from Adarouch, Central Morocco (Said \& Rodríguez, 2008; p. 17-18, pl. 2, fig. g), and represented by a single specimen in the Jerada Basin, eastern Morocco (Aretz, 2010, p. 329, fig. 4i, k). The Spanish specimens have been identified with the type species A. cuspiforma Semenoff-Tian-Chansky, 1974, and the previously documented Moroccan specimens have been left in open nomenclature. In all those cases, the transeptal dissepiments are of second order. On the other hand, the specimens from the Tindouf biostrome show a wide lonsdaleoid dissepimentarium. This feature plus the differences in the dimensions allow creating a new species.

\section{Axoclisia cf. coronata (Fabre, 1955)}

(Figs 201-n, 21)

Material. One single specimen (DO1/U-34); 2 transverse and 1 longitudinal thin sections.

Location, horizon and age. From the plain to the south of the Djebel Ouarkziz escarpment, $10 \mathrm{~km}$ west of the road from Zag to Assa, Tindouf Basin, S. Morocco. Biostrome (bed U), upper member, Djebel Ouarkziz Fm. early Bashkirian.

Description. Solitary, trochoid coral without the apex. The wall is only partly preserved, thin and undulose. The diameter in the adult stage is $25 \mathrm{~mm}$. The tabularium diameter reaches $15.4 \mathrm{~mm}$ and the axial structure diameter is $8.5 \mathrm{~mm}$. There are 37 long major septa that reach the border of the axial structure (Fig. 21); they are thin in the dissepimentarium and thick in the tabularium and become slightly sinuous axially. The minor septa are very thin and long, reaching the outer tabularium. The septa are frequently interrupted by large transeptal (lonsdaleoid) dissepiments (Figs 201, 20m). The outer tabularium wall is slightly thickened and prominent in the young stage (Fig. $20 \mathrm{~m}$ ) and in longitudinal section (Figs 20m-n). The axial structure is wide, about $1 / 3$ of the diameter. Its boundary is clear, marked by thickened tabulae. It lacks a median lamella and is composed of almost as many radial lamellae as septa (c. 35), and axial concentric tabulae (8-10 rows) that in longitudinal section show a semicircular shape and dense packing. The periaxial tabulae are concave and horizontal or variably declined to the periphery or to the axis. The dissepimentarium is wide, $1 / 2$ radius of corallite; it is composed of regular and transeptal dissepiments of 


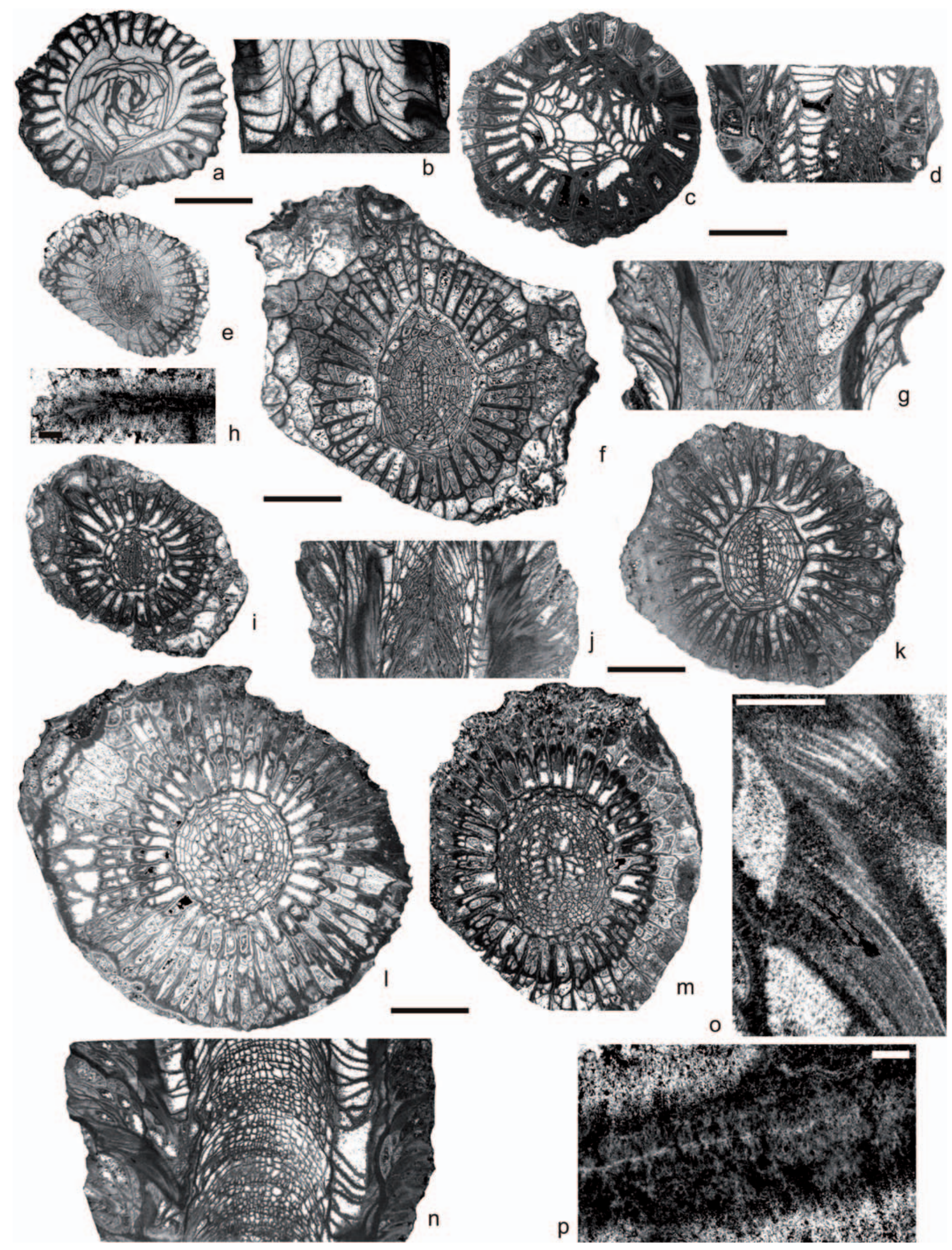




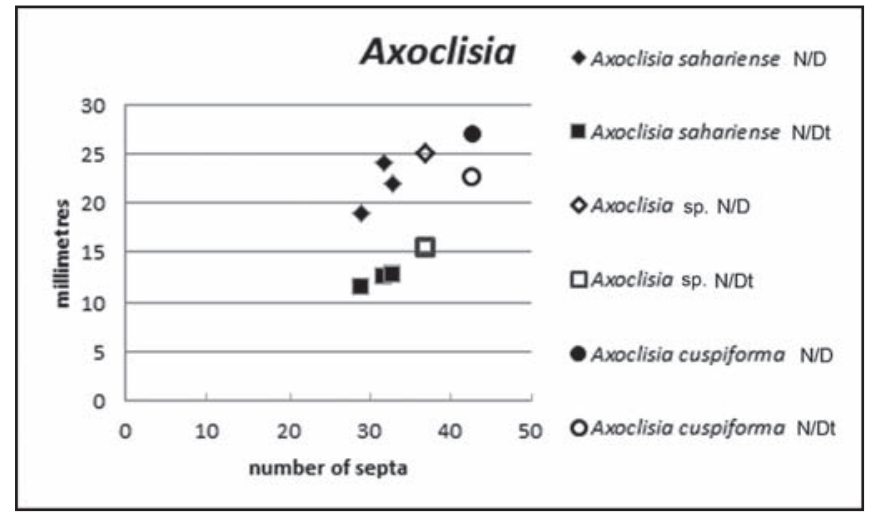

Figure 21. Plot of corallite diameter (D) and tabularium diameter (Dt) versus number of septa (N) in Axoclisia sahariensis sp. nov. (n=3), Axoclisia cf. coronata $(\mathrm{n}=1)$ and the type species Axoclisia cuspiforma.

first (few) and second order. In longitudinal section they show a low inclination in the periphery that increases close to the tabularium.

The microstructure of the septa is fibrous with fibres organized in fascicles (Figs 20o-p). Some lamellar thickenings occur on the tabulae, dissepiments and some parts of the septa.

Remarks. The described specimen shows a typical clisiophylloid axial structure and transeptal dissepiments of the second order. Consequently, it fits in the diagnosis of the genus Axoclisia. However, it is easily distinguished from the type species (A. cuspiforma) and from most other species assigned to the genus (see remarks on Axoclisia sahariense), in lacking a thick median lamella in a welldefined rounded axial structure, and in showing some second order transeptal dissepiments. The features of our specimen are closest to Axophyllum? coronatum (Fabre) whose holotype specimen was also figured by SemenoffTian-Chansky (1974, pl. 34, figs 5-6). However, the axial structure is less complex and does not show the concentric rings with different zones of densely packed and loosely arranged tabellae. In addition, our specimen is much smaller than the specimen of Fabre. Thus, as we have only one single incomplete specimen, it is referred to as Axoclisia cf. coronata.

\section{Genus Actinocyathus d'Orbigny, 1849}

Diagnosis (modified slightly after Hecker, 2010). Typically cerioid. Cardinal and counter septa commonly indiscernible. Axial column typically dibunophylloid. Periaxial tabulae commonly complete, seldom divided. Biform morphology of tabularium locally expressed with tabellae in position I, steeper abaxially declined than tabellae in position II. Dissepimentarium commonly wide, lonsdaleoid dissepiments thin, except for locally slightly dilated, vertically inclined inner margins of innermost dissepiments.

Actinocyathus sarytschevae (Dobrolyubova, 1958) (Figs 22, 23a-b)

Material. Two specimens (DO1/U-25, 148); 4 transverse and 2 longitudinal thin sections.

Location, horizon and age. From the plain to the south of the Djebel Ouarkziz escarpment, $10 \mathrm{~km}$ west of the road from Zag to Assa, Tindouf Basin, S. Morocco. Biostrome (bed U), upper member, Djebel Ouarkziz Fm. early Bashkirian.

Description. Fragments of cerioid colonies. Corallites 15 to $22 \mathrm{~mm}$ wide with tabularium diameter 7 to $10 \mathrm{~mm}$. Major septa 33 to 35 in number (Fig. 22). Major and minor septa long, penetrate the dissepimentarium, where they are thin, and thick in the tabularium. Axial structure large, reaching more than $1 / 2$ of the tabularium diameter. Composed of a median lamella irregular, usually thin, 10 to 30 radial lamellae and conical axial tabulae. Periaxial tabulae concave, sub-horizontal. Wide dissepimentarium composed of lonsdaleoid dissepiments variable in size and one or two inner rows of interseptal dissepiments (Fig. 23a).

Figure 20. a-d) Gangamophyllum sp.; (a-b) specimen DO1/U-42; (a) transverse section; (b) longitudinal section; (c-d) specimen DO1/U-66; (c) transverse section; (d) longitudinal section. e-k) Axoclisia sahariense; (e-h) specimen DO1/U-59 (holotype); (e) tranverse section in young stage; (f) transverse section in adult stage; (g) longitudinal section; (h) detail of one septum showing fibrous microstructure. i-k) Specimen DO1/U-76 (paratype); (i) tranverse section in young stage; (j) longitudinal section; (k) transverse section in adult stage. l-p) Axoclisia cf. coronata, specimen DO1/U-34; (l) transverse section in adult stage; (m) transverse section in young stage; (n) longitudinal section; (o) detail of tangential cut of one septum in longitudinal section, showing bands of fibers forming growth lamination; (p) detail of one septum in transverse section, showing fascicles of fibers. All scale bars except $\mathrm{h}, \mathrm{o}$ and $\mathrm{p}=5 \mathrm{~mm}$. Scale bars for $\mathrm{h}, \mathrm{o}$ and $\mathrm{p}=100 \mu \mathrm{m}$. 


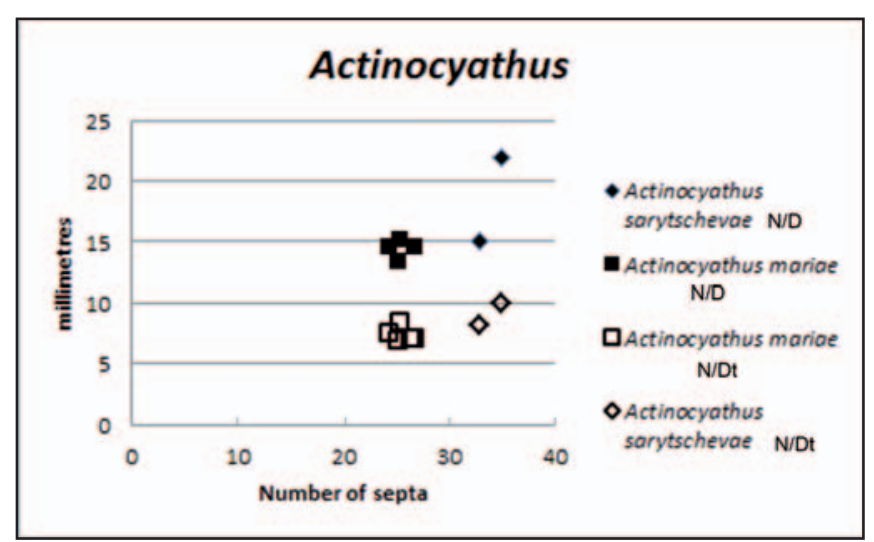

Figure 22. Plot of corallite diameter (D) and tabularium diameter (Dt) versus number of septa $(\mathrm{N})$ in Actinocyathus sarytschevae $(\mathrm{n}=2)$, and Actinocyathus mariae sp. nov. $(n=5)$.

Microstructure composed of fibers organized in fascicles (Fig. 23b), both in the septa and in radial lamellae. Wall, dissepiments and tabulae show a basal microgranular layer and fibrous thickenings.

Remarks. In spite of the geographical distance and the stratigraphical age difference (the type is early Serpukhovian in age), the specimens from the Tindouf biostrome fit completely with features of the Russian species, and their dimensions are in the lower ranges. This is in concordance with the observation of Rodríguez et al. (2011, 2013), who pointed out that the first appearances of many rugose coral species in the Tindouf; Basin occur later than in northern areas of the Western Palaeotethys. In this case, it is notable that all species of Actinocyathus recorded in the lower member of the Djebel Ouarkziz Formation (Serpukhovian) belong to the A. floriformis group (Rodríguez et al. 2011, 2013; see Hecker, 1997, 2010), whereas both species recorded in the biostrome of the upper member of the Djebel Ouarkziz Formation (Bashkirian) belong to the $A$. crassiconus group (Actinocyathus sarytschevae and A. mariae sp. nov). A. sarytschevae is distinguished from $A$. mariae by its larger number of septa, with no overlap in range for corallites of similar size, and thinner less conspicuous median lamella in the axial structure (see below).

\section{Actinocyathus mariae sp. nov.}

(Figs 22, 23c-h)

\section{Synonymy.}

pp 1958 Actinocyathus subcrassiconus subcrassiconus; Dobrolyubova, p.104

2010 Lonsdaleia (Actinocyathus) sp. B; Hecker, p. 322, Fig. 1i, j.
Derivatio nominis. The name of the species is dedicated to Maria Hecker, who revised the genus in the Russian platform and described similar forms.

Holotype. Specimen DO1/U-27; rest of the specimens collected in the same bed are regarded as paratypes.

Type locality, horizon and age. From the plain to the south of the Djebel Ouarkziz escarpment, $10 \mathrm{~km}$ west of the road from Zag to Assa, Tindouf Basin, S. Morocco. Biostrome (bed U), top beds of upper member, Djebel Ouarkziz Fm.; early Bashkirian.

Material. 5 colonies and some fragments (DO1/U-22, 23, 24, 27, 149); 14 transverse and 4 longitudinal thin sections.

Diagnosis. Actinocyathus having corallites with 6 to $9 \mathrm{~mm}$ in tabularium diameter, 23 to 28 major septa; axial structure having a median lamella, 10-30 radial lamellae and conical tabulae. Wide dissepimentarium composed of lonsdaleoid dissepiments variable in size, usually not very large. Minor septa long.

Description. Massive cerioid colonies variable in size. In the recorded collection they vary from 5 to $40 \mathrm{~cm}$ in diameter and 5 to $30 \mathrm{~cm}$ high. Some parts of the colonies may be subcerioid. Corallites 13 to $16 \mathrm{~mm}$ wide, with tabularium diameter 6 to $9 \mathrm{~mm}$. Major septa 23 to 28 in number (Fig. 22). Major and minor septa penetrate the dissepimentarium, where they are thin, and thick in the tabularium. Minor septa are typically long. Axial structure approximately $1 / 2$ of the of the tabularium diameter. Median lamella long and straight to lens-shaped and thickened; radial lamellae thin and variable in number, usually 10 to 30 (Figs 23c, 23f, 23h). Axial tabellae typically conical; their spacing varies strongly from 0.15 to $0.5 \mathrm{~mm}$. Periaxial tabellae sub-horizontal to somewhat declined towards the axis and somewhat more spaced than axial tabellae (Figs 23d-23e). Lonsdaleoid dissepiments variable in size, usually not very large, except in the more extended corners of the corallites, moderately declined towards the axis.

Microstructure identical to that of $A$. sarytschevae (Fig. 23g).

Remarks. The specimens from the Tindouf biostrome show identical features and measurements to those described by Hecker (2010) as Lonsdaleia (Actinocyathus) $\mathrm{sp}$. B. The dimensions and number of septa fit within the lowest range of Actinocyathus sp. B. The only difference is the number of radial lamellae, which are somewhat higher in the Russian specimens. Those differences could be explained by ecologic and biogeographical factors. 

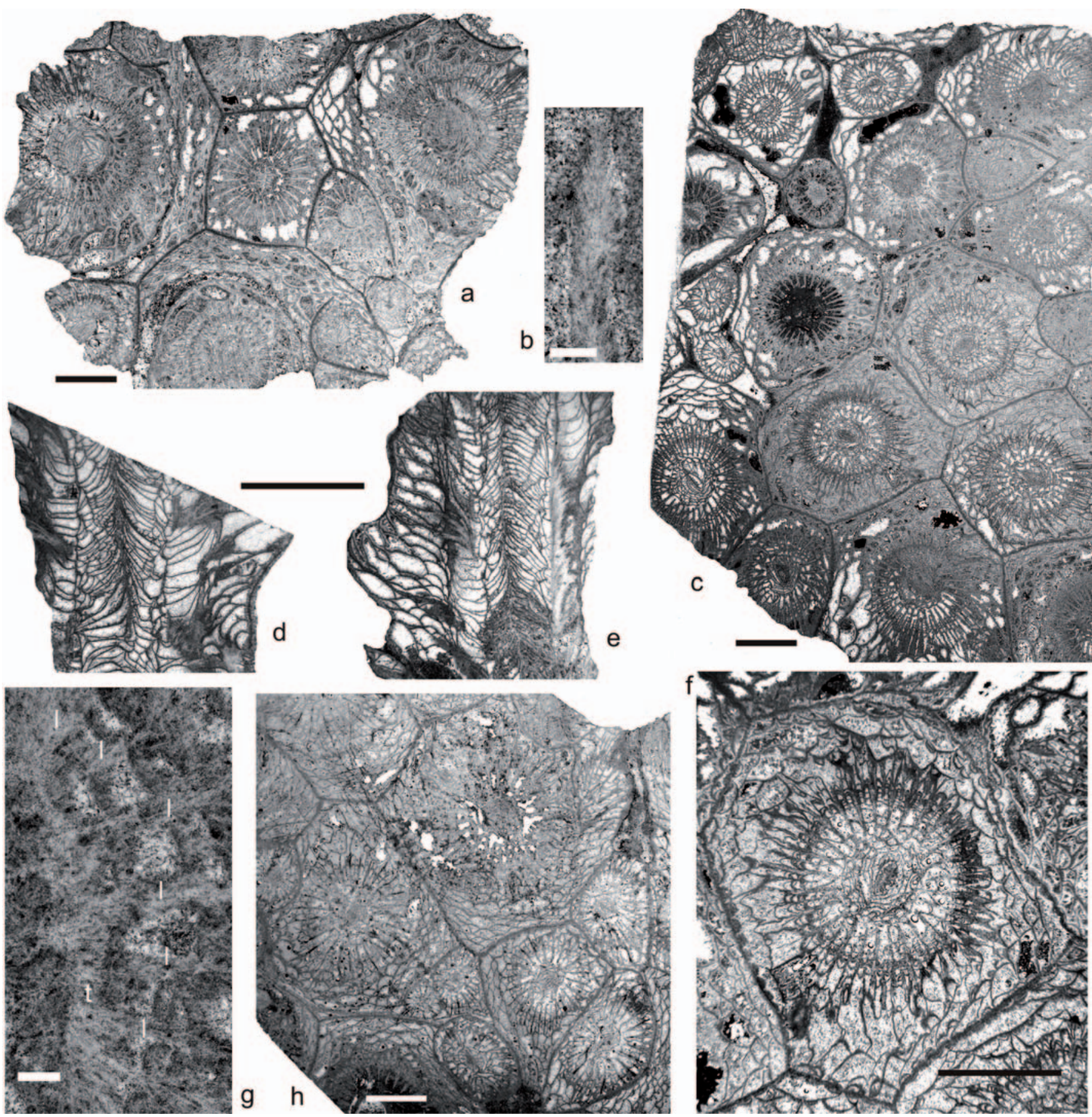

Figure 23. a-b) Actinocyathus sarytschevae, specimen DO1/U-25; (a) transverse section showing several corallites; (b) detail of the inner border of a septum showing fibrous microstructure; scale bar $=100 \mu \mathrm{m}$. c-h) Actinocyathus mariae; (c-g) specimen DO1/U-27 (holotype); (c) general view of a portion of the colony; (d-e) longitudional sections of two corallites; (f) tranverse section, detail of a corallite showing the key features of the species; (g) detail of the axial structure; radial lamellae (l) show fascicles of fibres and tabulae $(\mathrm{t})$ show also fibrous microstructure; scale bar $=100 \mu \mathrm{m}$. h) Specimen DO1/U-24 (paratype); general view of a portion of the colony. Scale bars for a, c-f and $\mathrm{h}=5 \mathrm{~mm}$. 


\section{DISCUSSION}

The assemblage and type of preservation of the corals from the Tindouf biostrome indicate an environment favourable for the development of corals, although at times highly unstable. In the lower part of the biostrome most of the solitary corals are fragmented and partially eroded. In addition, many broken branches of fasciculate corals occur everywhere in the beds. Fragmentation occurs also in specimens that are embedded in the rock, indicating that remobilization was prior to the sedimentation. However, the presence of some entire specimens showing little or no erosion and some entire fasciculate and massive colonies in growth position implies that the corals did not suffer prolonged transport, but were winnowed locally in the same environment where they lived. We can deduce from this that the environment was a shallow-water platform that suffered periodic storms, and that the biostrome containing many large in situ colonies, particularly in the upper part, could be considered parautochthonous.

The coral assemblage shows some typical Mississippian taxa (Dibunophyllum bipartitum, Palaeosmilia murchisoni, Palastraea regia, Diphyphyllum maximum, Actinocyathus sarytschevae), some indeterminate species belonging to typical Mississippian genera (Arachnolasma sp., Gangamophyllum sp.) and some new or unusual species, not present in older rocks, but also belonging to Mississippian genera (Palaeosmilia ressoti, Siphonodendron tindoufense sp. nov., Siphonodendron ouarkzizense sp. nov., Axophyllum moroccoense sp. nov., Axoclisia sahariense sp. nov., Axoclisia cf. coronata, Actinocyathus mariae sp. nov.). Consequently, it appears to be a typical Mississippian assemblage with some endemic forms. However, the foraminifers and conodonts recorded in the same beds indicate a early Bashkirian age for the biostrome. As stated previously, the corals are not reworked from older rocks. Thus, the inevitable conclusion is that the corals are of "Mississippian" type, but yet persisted into the Bashkirian (Early Pennsylvanian). This is not a new scenario, because it has been described previously in different parts of the world, even with some of the species or genera in common. Kossovaya (1996) indicated the presence of Palaeosmilia murchisoni and Diphyphyllum carinatum in the Bashkirian from Novaya Zemlya. Fedorowski \& Bamber (2012) and Fedorowski et al. (2012) described the presence of Dibunophyllum bipartitum, Palaeosmilia murchisoni, Londaleia duplicata and Tizraia sp. aff. "Diphyphyllum" carinatum in the Bashkirian from Ellesmere Island, Arctic Canada accompanied by Lower Bashkirian foraminifers. In addition Rodríguez (1984) described the presence of the Mississippian genera Dibunophyllum, Caninostrotion, Nemistium and Kizilia in what he regarded as probable Serpukhovian rocks in the Cantabrian Mountains, N. Spain, but which have been dated subsequently as Bashkirian, on the basis of foraminiferal and algal assemblages
(Coronado \& Rodríguez, 2009). However, the persistence of Mississippian corals in the Early Pennsylvanian is not a well recognized fact. Most Bashkirian (and in some cases also Serpukhovian) coral assemblages described around the world show many new occurrences and, typically, Pennsylvanian assemblages contain different corals from those of the Mississippian, highlighting the renewal of faunas as a well known event (Fedorowski, 1981).

Some questions arise in that situation: What is the reason for the renewal of coral faunas? What are the factors that allowed some corals to survive in some refuges? What features are in common in those refuges?

The most commonly invoked reason for the crisis of coral faunas in the Serpukhovian is the glaciation that had its nucleus in Gondwana. During the Serpukhovian the western European basins were located near the equator following most accepted reconstructions (Scotese, 2002; Blakey, 2007, 2008). Consequently, the Saharan basins, including Tindouf, should be located at least $20^{\circ}$ or $25^{\circ}$ south of the equator. The glaciation should, theoretically, therefore, affect less the equatorial coral assemblages from Europe than those assemblages in the northern Gondwana basins. However, paradoxically, the faunas from Europe were more strongly affected, whereas the faunas from northern Gondwana found a refuge in the Tindouf Basin. This was despite the presumed higher latitude position of Tindouf and the inferred closer proximity to the nucleus of continental glaciation in southern Africa. In this case, the marine currents could be important in warming the intracratonic basins from northern Gondwana. If the equatorial current flowing from east to west encountered continental masses (e.g., the Iberian Massif), it could be deflected southwards and provide warm waters for the Saharan basins.

The Gondwanan glaciation could be a factor, but not necessarily the only one. The western European faunas should be also located in warm (equatorial) waters but they did not survive. The reason in this case for the coral extinction could be the tectonic instability suffered by the region during the Serpukhovian. At that time, the Variscan belt was becoming very active with the merging of Gondwana and Laurussia. In addition, the mountains became progressively elevated, producing a greater amount of terrigenous material which was introduced to the surrounding basins and platforms. It produced paralic environments that are dominant in the present-day European area, and provoked the extinction of the corals in those regions. On the other hand, the Saharan basins, located in epicontinental seas were much more stable and provided a good refuge for the corals, which flourished in the extensive tropical carbonate platform.

Examination of the other refuge areas, such as Ellesmere Island (Fedorowski \& Bamber, 2012; Fedorowski et al., 2012) and Novaya Zemlya (Kossovaya, 1996) indicates carbonate platforms that were also located on the border of large cratons, in this case in northern latitudes, that 
could be similar scenarios to those of the Tindouf Basin south of the equator. Thus, stable epicontinental seas in mid to low latitudes seem to be the best refuges for coral survivors during the late Serpukhovian extinction event (see McGhee et al., 2012). The example provided by the Cantabrian Mountains (Rodríguez, 1984) is different, because it was located on the border of a shallow-water platform with high carbonate productivity during the entire Carboniferous. In this case, the area was unstable, because the border of the platform was collapsing into a turbiditic basin, but the combination of warm waters and absence of terrigenous material, probably also helped to provide a suitable refuge for corals.

The results of the combination of warm waters provided by ocean currents and tectonic stability allowed some species to be very conservative and survive basically without changes (Dibunophyllum bipartitum, Palaeosmilia murchisoni, Palastraea regia, Actinocyathus sarytschevae). On the other hand, some other species found the same conditions suitable for evolutionary development and emergence of new species (Siphonodendron tindoufense sp. nov., S. ouarkzizense sp. nov., Axophyllum moroccoense sp. nov., Axoclisia sahariense sp. nov., Actinocyathus mariae sp. nov.). Those conditions extended along a vast area in the northern Gondwana border, because the assemblage recorded in the western Djebel Ouarkziz, is basically identical to that recorded $200 \mathrm{~km}$ to the east in the same mountain range in Algeria (Semenoff-Tian-Chansky, 1974, 1985). Similar biostromes and coral assemblages seem to be present also in the Reggan, Ahnet and Taoudenni basins (Semenoff-Tian-Chansky, 1985; Legrand-Blain et al., 1989), which demonstrate the likelihood that epeiric seas developed over 1000s $\mathrm{km}^{2}$ in the Saharan region.

\section{CONCLUSIONS}

1. The coral assemblage recorded from the biostrome at the top of the upper member in the Djebel Ouarkziz Fm in the western part of the Djebel Ouarkziz in the Tindouf Basin is composed of 10 genera and 14 species (5 of which are new): Dibunophyllum bipartitum, Arachnolasma sp., Palaeosmilia murchisoni, Palastraea regia, Palaeosmilia ressoti, Siphonodendron tindoufense sp. nov., Siphonodendron ouarkzizense sp. nov., Diphyphyllum maximum, Axophyllum moroccoense sp. nov., Gangamophyllum sp., Axoclisia sahariense sp. nov., Axoclisia cf. coronata, Actinocyathus sarytschevae and Actinocyathus mariae sp. nov.).

2. It represents essentially a Mississippian-type coral fauna but with some evolved species. However, its age, as determined by foraminifers, is early Bashkirian (Early Pennsylvanian).

3. The presence of Mississippian-like corals in the Bashkirian indicates that the epicontinental basins in northern Gondwana were a refuge for coral faunas during the Serpukhovian extinction event.

4. The persistence of the Mississippian assemblages in the Bashkirian from northern Gondwana was probably due to a combination of warm waters and tectonic stability.

5. The coral assemblage from the Tindouf biostrome is similar to those from Ellesmere Island and Novaya Zemlya, where similar conditions have been identified in the Bashkirian.

\section{ACKNOWLEDGEMENTS}

The present research has been carried out with the funds provided by the Research projects CGL2009-10340BTE and CGL2012-30922BTE of the Spanish Ministerium or Research and Innovation. This article is a contribution to the IGCP 596. The authors thank the cooperation of the Department of Mines and Development of the Ministère de l'Energie et des Mines of Morocco. The thin sections used for this study have been prepared by Isabel Díaz Mejías. This paper has benefited from the constructive comments of Prof. Edouard Poty and Dr. Maria Hecker.

\section{REFERENCES}

Aretz, M. 2002. Habitatanalyse und Riffbildungspotential kolonialer rugoser Korallen im Unterkarbon (Mississippium) von Westeuropa. Kölner Forum Geologie und Paleontologie, 10/2002, 1-155.

Aretz, M. 2010. Rugose corals from the upper Viséan (Carboniferous) of the Jerada Massif (NE Morocco): taxonomy, biostratigraphy, facies and palaeobiogeography. Palaeontologische Zeitschrift, 84(3), 323-344.

Aretz, M. 2011. Corals from the Carboniferous of the central Sahara (Algeria): the collection of "Marie Legrand-Blain". Geodiversitas, 33 (4), 581-624.

Blakey, R.C. 2007. http://jan.ucc.nau.edu/ rcb7/nam.html (North America Palaeogeographic Maps).

Blakey, R.C. 2008. Gondwana paleogeography from assembly to breakup; a 500 m.y. odyssey. Special Paper, Geological Society of America, 441, 1-28.

Conrad, J. 1985. North Africa - Northwestern and central Saharan areas: Tindouf Basin. In: The Carboniferous of the world II: Australia, Indian subcontinent, South Africa, South America and North Africa (eds Wagner, R.H., Winkler Prins, C.F. \& Granados, L.F.). IUGS Publication No. 20. Instituto Geológico y Minero de España/ Empresa Nacional Adaro de Investigaciones Mineras S.A, Madrid. 325-327.

Conrad, J. \& Legrand-Blain, M. 1971. Titanaria africana nov. sp., un noveau Gigantoproductide du Namurien saharien. Bulletin de la Société d'Histoire Naturelle d'Afrique du Nord, 62, 107-131. 
Coronado, I. \& Rodríguez, S. 2009. Análisis de microfacies de los montículos de la Formación Cosgaya. Sección de Las Ilces, Pensilvánico, Cantabria [Microfacies analysis of the Cosgaya Formation mounds. Las Ilces Section, Pennsylvanian, Cantabria, N Spain]. Coloquios de Paleontología, 59, 61-91.

Cózar, P., Medina-Varea, P., Somerville, I.D., Vachard, D., Rodríguez, S., Said, I. (in press). Foraminifers and conodonts from the late Viséan to early Bashkirian succession in the Saharan Tindouf Basin (southern Morocco): biostratigraphic refinements and implications for correlations in the western Palaeotethys. Geological Journal, doi: 10.1002/gj2519.

Denayer, J., Poty, E. \& Aretz, M. 2011. Uppermost Devonian and Dinantian rugose corals from Southern Belgium and surrounding areas. In: Field Guides $11^{\text {th }}$ International Symposium on Fossil Cnidaria and Porifera, Liège 2011. Kölner Forum Geologie und Paleontologie, 20, 151201.

Dobrolyubova, T.A. 1958. Lower Carboniferous colonial tetracorals of the Russian Platform. Transactions of the Palaeontological Institute, Academy of Sciences, USSR, 70: 1-226. Moscow. [in Russian]

Dybowski, W.N. 1873. Beschreibung einiger neuen oder wenig bekennten Arten der Zoantharia rugosa aus der Kohlenformation Russlands. Zapadnogo Imperialnogo Minerali ob-va, 8, 102-116.

Ehrenberg, C.G. 1834. Beitrage zur physiologischen Kenntniss der Corallenthiere im allgemeinen, und besonders des rothen Meeres, nebst einem Versuche zur physiologischen Systematik derselben. Physiologishen Ahandlungen könichliche Akademie Der Wissenschaften Berlin 1832, 225-380.

Fabre, J. 1955. Deux polypiers du Viséen dupérieur de Tindouf (Sahara N. W.): Caninophyllum archiaci (M.E. et $\mathrm{H})$ var. densa n. var. et Carcinophyllum coronatum nov. sp. Annales de la Societé Géologique du Nord, 75, 8-15.

Fedorowski, J. 1971. Aulophyllidae (Tetracoralla) from the Upper Visean of Sudetes and Holy Cross Mountains. Paleontologica Polonica, 24, 1-137.

Fedorowski, J. 1981. Carboniferous corals: distribution and sequence. Acta Palaeontologica Polonica, 26(2), 87-160.

Fedorowski, J. \& Bamber, E.W. 2012. Paleobiogeographic significance of Bashkirian (Pennsylvanian) rugose corals from northernmost Ellesmere Island, Arctic Canada. Geologica Belgica, 15(4), 350-354.

Fedorowski, J. Bamber, E.W. \& Baranova, D.V. 2012. An unusual occurrence of Bashkirian (Pennsylvanian) rugose corals from the Sverdrup Basin, Arctic Canada. Journal of Paleontology, 86(6), 979-995.

Frey, H. \& Leuckart, R. 1847. Lehrbuch der Anatomie der wirbelloser Tiere. Ledopold Voss, Leipzig, 1-626.

Gorsky, I.I. 1938. Carboniferous corals of Novaya Zemlya. [Kammennougol'nyi korally Novoy Zemli]. In: Paleontologiya Sovetskoy Arktiki, Bessoyunzii Arkticheskii Institut (ed. Nalivkin, D.V.), 93(2), Leningrad (In Russian). 7-221.

Gorsky, I.I. 1951. Carboniferous and Permian corals of Novaya Zemlya. [Kammennougol'nye i permskie korally
Novoy Zemli]. Trudy Nauchno-issledovatel'skogo instituta geologii Arktiki, 32, 5-168. (In Russian)

Grabau, A.W. 1922. Palaeozoic corals of China. Part 1. Tetraseptata. Palaeontologica Sinica Series B, II, 1-76.

Hatscheck, B. 1888. Lehrbuch der Zoologie: eine morphologische Übersicht des Thierreiches zur Einführung in das Studium dieser Wissenschaft. G. Fischer, Jena, 1-432.

Hecker, M. 1997. Evolution, ecology and variability of Actinocyathus d'Orbigny 1849 (Rugosa) in the Moscow Basin during the latest Viséan and Serpukhovian. Boletin de la Real Sociedad Española de Historia Natural, (Sección Geológica), 91 (1-4), 107-115.

Hecker, M. 2010. Some aspects of evolution in the Lonsdaleia (Actinocyathus) crassiconus species-group. Palaeoworld, 19 (3-4), 316-324.

Hill, D. 1938-1940. A monograph on the Carboniferous rugose corals of Scotland. Palaeontological Society of London Monograph, Pt. 1 (1-78), Pt. 2 (79-114), Pt. 3 (115-204).

Hill, D. 1981. Rugosa and Tabulata. In: Treatise on Invertebrate Paleontology Part F (Supplement 1) (ed. Teichert, C.). Geological Society of America and University of Kansas Press, Boulder Colorado and Lawrence, Kansas (2 vols), 1-762.

Khoa, N.D. 1977. Carboniferous rugosa and heterocorallia from boreholes in the Lublin region (Poland). Acta Palaeontologica Polonica, 22(4), 301-404.

Kossovaya, O. 1996. The mid-Carboniferous rugose coral recovery. In: Biotic Recovery from Mass Extinction Events (ed. Hart, M.B.). Geological Society London Special Publications, 102, 187-199.

Legrand-Blain, M., Conrad, J., Coquel, R., Lejal-Nicol, A., Lys, M., Poncet, J. \& Semenoff-Tian-Chansky, P. 1989. Carboniferous Palaeobiogeography of North Africa. In: C. R. 11ème Congres International Stratigraphie et Géologie Carbonifère, Beijing 1987, 4, 216-230, Beijing.

Lonsdale, W. 1845. Description of some characteristic Palaeozoic corals of Russia In: The geology of Russia in Europe and Ural Mountains, 1, Geology. (Murchison, R.I., de Verneuil, E. \& von Keyserling, A.). John Murray, London, 591-634.

Mamet, B., Choubert, G. \& Hottinger, L. 1966. Note sur le Carbonifère du Djebel Ouarkziz. Etude du passage Viséen au Namurien d'après les Foraminifères. Notes et Memoires du Service Géologique du Maroc, 198, 27, 7-21.

McCoy, F. 1844. A synopsis of the characters of the Carboniferous Limestone Fossils of Ireland, Dublin p. 5-207.

McCoy, F. 1849. On some new genera and species of Palaeozoic Corals and Foraminifera. Annals \& Magazine of Natural History, Series 2, 3, 1-20, 119-136.

McCoy, F. 1851. A description of some New Mountain Limestone Fossils. Annals and Magazine of Natural History, Series 2, 7, 167-175.

McGhee, G.R. JR, Sheehan, P.M., Bottjer, D.J. \& Droser, M.L. 2012. Ecological ranking of Phanerozoic biodiversity crises: The Serpukhovian (early Carboniferous) crisis had a greater ecological impact than the end-Ordovician. Geology, 40, 147-150. 
Menchikoff, N. \& Hsu, T-Y. 1935. Les polypiers carbonifères du Sahara occidental. Geological Society of France, Bulletin, 4-5, 229-261.

Milne-Edwards, H. \& Haime, J. 1848. Recherches sur les polypiers, Premier général. Annales des Sciences Naturelles, 9, 37-89.

Milne-Edwards, H. \& Haime, J. 1850-1855. A Monograph of the British fossil corals 1850 (p.1-71), 1852 (p.147-210), 1853 (p. 211-244), 1855 (p.245-299). Palaeontographical Society, London.

Milne-Edwards, H. \& Haime, J. 1851-1855. Monographie des polypiers fossils des terrains palaeozoiques, précédée d'un tableau general de la classification des Polypes. Archives du Museum d 'Histoire Naturelle de Paris, Paris, 1-468.

Orbigny, A.d'. 1849. Notes sur des polypiers fossiles. Victor Masson, Paris, 1-12.

Orbigny, A.d'. 1852. Cours élémentaire de paléontologie et de géologie stratigraphique, 2(1), Victor Masson, Paris, 1-276.

Phillips, J. 1836. Illustration of the geology of Yorkshire. Part II. The Mountain Limestone district, John Murray, London, 1-253.

Poty, E. 1981. Recherches sur les Tétracoralliaires et les Hétérocoralliaires du Viséen de la Belgique. Mededelingen Rijks Geologische Dienst, 35, 1-161.

Rodríguez, S. 1984. Corales Rugosos del Carbonifero del Este de Asturias. PhD Thesis, Universidad Complutense de Madrid 109/84.

Rodríguez, S., Rodriguez-Curt, L. \& Hernando, J. M. 2001. Estudio de los aulophyllidae (rugosa) del viseense superior de la unidad de la Sierra del Castillo (Cordoba, Espana). [Study of Aulophyllida (Rugosa) from the upper Visea of the Sierra del Castillo unit, Cordoba, Spain.] Coloquios de Paleontología, 52, 47-78.

Rodríguez, S., Hernando, J.M. \& Rodriguez-Curt, L. 2002. Estudio de los corales lithostrotiónidos del Viseense (Misisipiense) de la Unidad de la Sierra del Castillo (Córdoba, España). Revista Española de Paleontología, 17, 13-36.

Rodríguez, S. \& Somerville, I.D. 2007. Comparisons of rugose corals from the Upper Viséan of SW Spain and Ireland: implications for improved resolutions in late Mississippian coral biostratigraphy. In: Fossil Corals and Sponges. Proc. 9th International Symposium Fossil Cnidaria \& Porifera, Graz 2003. (eds Hubmann, B. \& Piller, W.E.). Schrift. Erdwissensch. Kom., 17, 275-305.

Rodríguez, S., Somerville, I.D., Said, I. \& Cózar, P. 2011. An upper Viséan (Asbian-Brigantian) coral succession at Djebel Ouarkziz (northern Tindouf Basin, southern Morocco). Abstract Volume, XI International Symposium on Fossil Cnidaria and Sponges, Liege. Kolner Forum Geologie und Paleontologie, 19, 147-148.
Rodríguez, S., Said, I., Somerville, I.D. \& Cózar, P. 2013. An upper Viséan (Asbian-Brigantian) and Serpukhovian coral succession at Djebel Ouarkziz (northern Tindouf Basin, southern Morocco). Rivista Italiana di Paleontologia e Stratigrafia, 119, 3-18.

Said, I. 2005. Estudio de los corales rugosos con disepimentos del Mississippiense del NE de la meseta marroquí (sectores de Adarouch y Agouaraï) (unpublished). PhD Thesis, Universidad Complutense de Madrid.

Said, I. \& Rodríguez, S. 2008. Descripción de los corales aulophyllidos del Viseense y Serpujoviense del área de Adarouch (Marruecos). Coloquios de Paleontología, 58, 13-40.

Scotese, C.R. 2002. http://www.scotese.com, (PALEOMAP website).

Salée, A.1913. Contribution a l'étude des polypiers du Calcaire Carbonifère de la Belgique, II, Le groupe des Clisiophyllides. Mémoires de L'Institut Géologique de l'Université de Louvain, 1, 179-293.

Semenoff-Tian-Chansky, P. 1974. Recherches sur les Tétracoralliaires du Carbonifére du sahara Occidental. Editions du Centre Nationale de la Recherche Scientifique. Ser. 6, Science de la Terre, 30, Paris, 1-316.

Semenoff-Tian-Chansky, P. 1985. Corals. In: The Carboniferous of the World, II, Australia, Indian subcontinent, South Africa, South America and North Africa (eds Wagner, R.H., Winkler-Prins, C.F. \& Granados, L.F.), IUGS Publication, 20, 374-381.

Somerville, I.D., Cózar, P., Said, I., Vachard, D., MedinaVarea, P. \& Rodríguez, S. 2013. Palaeobiogeographical constraints on the distribution of foraminifers and rugose corals in the Carboniferous Tindouf Basin, S. Morocco. Journal of Palaeogeography, 2, 1-18.

Thompson, J. 1874. Descriptions of new corals from the Carboniferous Limestone of Scotland. Geological Magazine, Series 2 (1), 556-559.

Thompson, J. 1880. Contribution to our knowledge of the Rugose corals from the Carboniferous Limestone of Scotland. Proceedings of Royal Philosophical Society Glasgow, 12, 225-261.

Thompson, J. \& Nicholson, H.A. 1876. Contribution to the study of the chief generic types of the Palaeozoic corals. Annals \& Magazine of Natural History, Series 4, 17 (6), 451-462.

Vuillemin, C. 1990. Les Tetracoralliaires (rugosa) du Carbonifère inférieur du Massif Amoricain (France). Cahiers de Paléontologie, 1-171.

Yu, C.C. 1934. Lower Carboniferous corals of China. Palaeontologica Sinica, 12 (3) (1933), 1-211. 
